\title{
Social Factors of Migration from Rural to Urban Areas with Special Reference to
} Developing Countries: The Case of Korea**

\section{Hyung-Kook Kim*}

\author{
Contents \\ Introduction \\ Part 1: Macro-scopic patterns of Korean internal migration, 1961-75 \\ 1. Where migrants go \\ 2. Who moves \\ 3. Why they move \\ Summary \\ Part 2: Behaviors of inmigrants to Seoul \\ 1. Decision-making of migration \\ 2. Job mobility of the inmigrants \\ 3. Settlement patterns of the inmigrants \\ 4. Living conditions of squatters \\ Summary \\ Part 3: Policies concerned with internal migration \\ 1. Seoul population dispersal plan in the national development strategy \\ 2. Squatter relocation policy \\ 3. Concluding remarks \\ References and bibliography
}

\section{Introduction}

This paper aims at elaborating social factors related to internal migration in a developing country, Korea. As of date, there is quite a lot of quality literature ${ }^{(1)}$ which provides a

\footnotetext{
*Assistant Professor, Department of Urban and Regional Planning, Graduate School of Environmental Studies, Seoul National University.

**Prepared for the meeting on the indicators of social factors of development, sponsored by UNESCO and held in Madrid, Spain, 9-12 June, 1980.
}

(1) Two authors in the literature are distinct: Findley (1977) and Shaw (1975). 
good overview of the current state of knowledge concerning internal migration in a com. prehensive and appropriate manner. This literature pays greater attention to internal migration in developing countries. For this reason, the discussion in this paper is confined to recent Korean experience. And social factors will be taken in a broader sense, that is, as societal one in that they may cover social, economic, cultural and psychological aspects. This is so because social aspects are closely interlocked with other sectoral elements.

This study will be made primarily on the basis of a literature survey covering qualitative reports as well as raw data such as population census. In this paper, internal migration is defined as the mobility of people between regions, which differs from residential mobility which happens within cities or urban areas. Furthermore, migration is conceived as implying socio-economic mobility. This point can be justified in the sense that urban-rural migration in the geographical sense is more likely to refer to job transfers from agricultural to non-agricultural activities in the socio-economic sense.

This paper is concerned with internal migration since the early $1960^{\circ} \mathrm{s}$ when Korea was about to begin its rapid economic development. The time-span of this study addresses itself to a close association between economic development and internal migration. Rapid industrialization (as represented by a high GNP growth rate of $9.4 \%$ per annum in the years of $1961 \sim 75$ ) that Korea has enjoyed during the past two decades has called for a large labor force which had to originate from rural sector. In due course, internal migration is attributed to other social changes such as the reorganization of the national space and urban expansion on the one hand, and achievement motivation ever-prevailing in every Korean's mind and nuclearization of the family structure on the other hand. To this effect, migration appears as a social issue.

This paper will begin with a brief review of the current state of Korean internal migration. The review will be made from a macro-scopic perspective. What follows is a closer examination of the experiences that inmigrants to Seoul undergo. This attempt may be justified on the ground that Seoul ever remains as a prime receptor of outmigrants from local cities and rural sectors to the extent that 6 out of 10 migrants were destined to the city in $1970 \sim 75$. Therefore, the second part of this paper concerning Seoul inmigrants will adopt a somewhat intermediate approach, as compared with the first part of the paper. While a macro-scopic, highly aggregate approach is good for an overview of general trends of internal migration, it is not specific enough to identify social factors of migration in regard to policy purposes. In this sense, an intermediate approach focusing on inmigrants 
to the big city as favored by most of the potential migrants in Korea will be called for as an alternative one, complementary to the built-in weakness of the aggregate approach.

Lastly, the paper ends with a brief description of the experiences and effects of, if any, migration policies. Until recently, Korea has experienced two major migration policies: one is a population dispersal policy aimed at pulling population from the capital city, and the other is a relocation policy undertaken within the Seoul metropolitan region. These policy experiences will be selectively discussed.

\section{Part I: Macro-scopic patterns of Korean Internal migration, 1961 75}

In examining the characteristics and patterns of internal migration, it is useful to discuss them from three perspectives: (1) where migrants go; (2) who moves; and (3) why they move.

\section{Where migrants go}

Urban orientation appears as a dominant mode in internal migration from 1961 1975. Urban inmigration from urban (39.2\%) and rural sectors (37.9\%) makes up a share of more than 70 per cent of total internal migration volume during the above time-period, as seen in Table 1. Two major trends may be seen in this urban orientation of internal migration. First, urban-to-urban migration in urban orientation started to win a marginal edge over urban inmigration originating from rural sectors by the beginning of the $1970^{\circ} \mathrm{s}$. Before the $1970^{\circ} \mathrm{s}$, rural-to-urban flow accounted for 4 out of 10 migrants, while urban-to-urban flow accounted for 3 out of 10 migrants. This trend, however, reversed itself during 1970 75. Four urban inmigrants out of ten came from the other urban sectors, whereas

Table 1. Directions of internal migration, based on "residence five years ago," by residence: Republic of Korea, 1961 75

\begin{tabular}{|c|c|c|c|c|c|c|c|c|}
\hline \multirow{2}{*}{$\begin{array}{l}\text { Directions } \\
\text { (From/to) }\end{array}$} & \multicolumn{2}{|c|}{$1961 \sim 66$} & \multicolumn{2}{|c|}{$1965 \sim 70$} & \multicolumn{2}{|c|}{$1970 \sim 75$} & \multicolumn{2}{|c|}{$1961 \sim 75$} \\
\hline & $A^{*}$ & B & A & B & A & B & $\mathrm{A}$ & B \\
\hline Urban/Urban & 500,433 & 31.7 & $|1,532,143|$ & 34.9 & $2,275,056$ & 44.2 & $4,307,632$ & 39.2 \\
\hline Rural/Urban & 587,597 & 40.7 & $1,826,665$ & 41.6 & $1,754,346$ & 34.1 & $4,168,608$ & 37.9 \\
\hline Urban/Rural & 153,550 & 10.7 & $387,07 \pi$ & 8.8 & 558,318 & 10.8 & $1,098,945$ & 10.0 \\
\hline Rural/Rural & 200,601 & 13.9 & 648,565 & 14.8 & 563,284 & 10.9 & $1,412,450$ & 12.9 \\
\hline Total & $1,442,182$ & $100.0 \%$ & $4,394,450$ & $100.0 \%$ & $5,150,994$ & $100.0 \%$ & $10,987,635$ & $100.0 \%$ \\
\hline
\end{tabular}


three out of ten migrants moved from the rural sectors. This pattern seems attributable to the fact that urban population in the nation increasingly approached to an even distribution point $(48.4 \%)$ with rural poulation $(51.6 \%)$ in 1975 , as referred to Table 2.

On the other hand, urban-to-rural, namely, reverse migration and rural-to-rural migration remained almost constant in terms of their proportions to the total volume of internal migration in the years of $1961 \sim 75$. But rural-to-rural migration decreased in number throughout the first half of the $1970^{\prime} \mathrm{s}$, compared with the decade of the $1960^{\prime} \mathrm{s}$. This fact seems attributable at most to a continuous decrease of rural population as an absolute number.

From the viewpoint of spatial mobility, it can be hardly overstated that the migration stream in Korea in the period of $1961 \sim 75$ centered on the big cities. A schematic diagram (Figure 1) showing inter-provincial net migration in 1969 70 provides a glimpse at the migration pattern primarily directed toward the big cities of Seoul and Pusan.

As far as inter-provincial migration flow is concerned, Seoul earned net gains from all the provincial boundaries of the national territory except for the remote island province of Jeju from 1961 1966. This trend has continued through 1966 1975 with a minor change in which Seoul regisiered a net loss to her neighboring province of Kyeong-gi in 1970 75 while she gained a poulation increase even from the Jeju island, as seen in Figure 2. This minor change of migration pattern in the spatial sense implies a substantive expansion of the zone of influence by Seoul. In other words, the Seoul population is shown to have undergone an extensive suburbanization process beyond the municipal boundary of Seoul into Kyeong-gi and, at the same time, new migrants from the rest of the country prefer to settle down in cities near enough to enjoy the attractive agglomeration economy of Seoul. In this connection, cities of Suwon, Anyang, and Boochun within a short reach of Seoul have increased in population at the rates of $5.6 \%, 8.0 \%$, and $13.6 \%$ per annum, respectively, far higher than the average urban population growth rate of $5.2 \%$ in $1970 \sim 75$.

Table 2. Population distribution by residence, $1960 \sim 75$

\begin{tabular}{|c|c|c|c|c|c|c|c|c|}
\hline \multirow{2}{*}{ Area } & \multicolumn{2}{|c|}{$\begin{array}{llll}1 & 9 & 6 & 0\end{array}$} & 19 & 66 & 19 & 70 & 19 & 75 \\
\hline & \multicolumn{2}{|c|}{$\mid$\begin{tabular}{c|c|}
$\begin{array}{c}\text { Population } \\
(1,000 \mathrm{~s})\end{array}$ & $\begin{array}{l}\text { istribution } \\
\text { (percent) }\end{array}$ \\
\end{tabular}} & \multicolumn{2}{|c|}{$\left.\left.\begin{array}{c}\text { Population } \\
(1,000 \mathrm{~s})\end{array}\right] \begin{array}{c}\text { Distribution } \\
(\text { percent })\end{array}\right]$} & \multicolumn{2}{|c|}{$\begin{array}{c}\begin{array}{c}\text { Population } \\
(1,000 \mathrm{~s})\end{array} \\
\begin{array}{c}\text { Distribution } \\
\text { (percent) }\end{array}\end{array}$} & \multicolumn{2}{|c|}{\begin{tabular}{|c|c|}
$\begin{array}{c}\text { Population } \\
(1,000 \mathrm{~s})\end{array}$ & $\begin{array}{c}\text { Distribution } \\
\text { (percent) }\end{array}$ \\
\end{tabular}} \\
\hline Rural & 17,788 & 71.2 & 19,213 & 65.8 & 17,859 & 60.3 & 17,888 & 51.6 \\
\hline $\mathrm{Jrb}$ & 3,592 & 14.4 & 4,761 & 16.3 & 5,110 & 16.2 & 7,449 & 21.5 \\
\hline $\begin{array}{l}\text { Metro } \\
\text { olit }\end{array}$ & 3,609 & 14. 4 & 5,219 & 17.9 & 7,402 & 23.5 & 9,344 & 26.9 \\
\hline All areas & 24,989 & 100.0 & 29,193 & 100.0 & 31,469 & 100.0 & 34,681 & 100.0 \\
\hline
\end{tabular}

*Metropolitan areas are defined the two biggest cities of Seoul and Pusan.

Source: Economic Planning Board, Korea Statistical Yearbook: 1976. 
Fig 1: Inter-provincial net migration in 1969 $70^{*}$

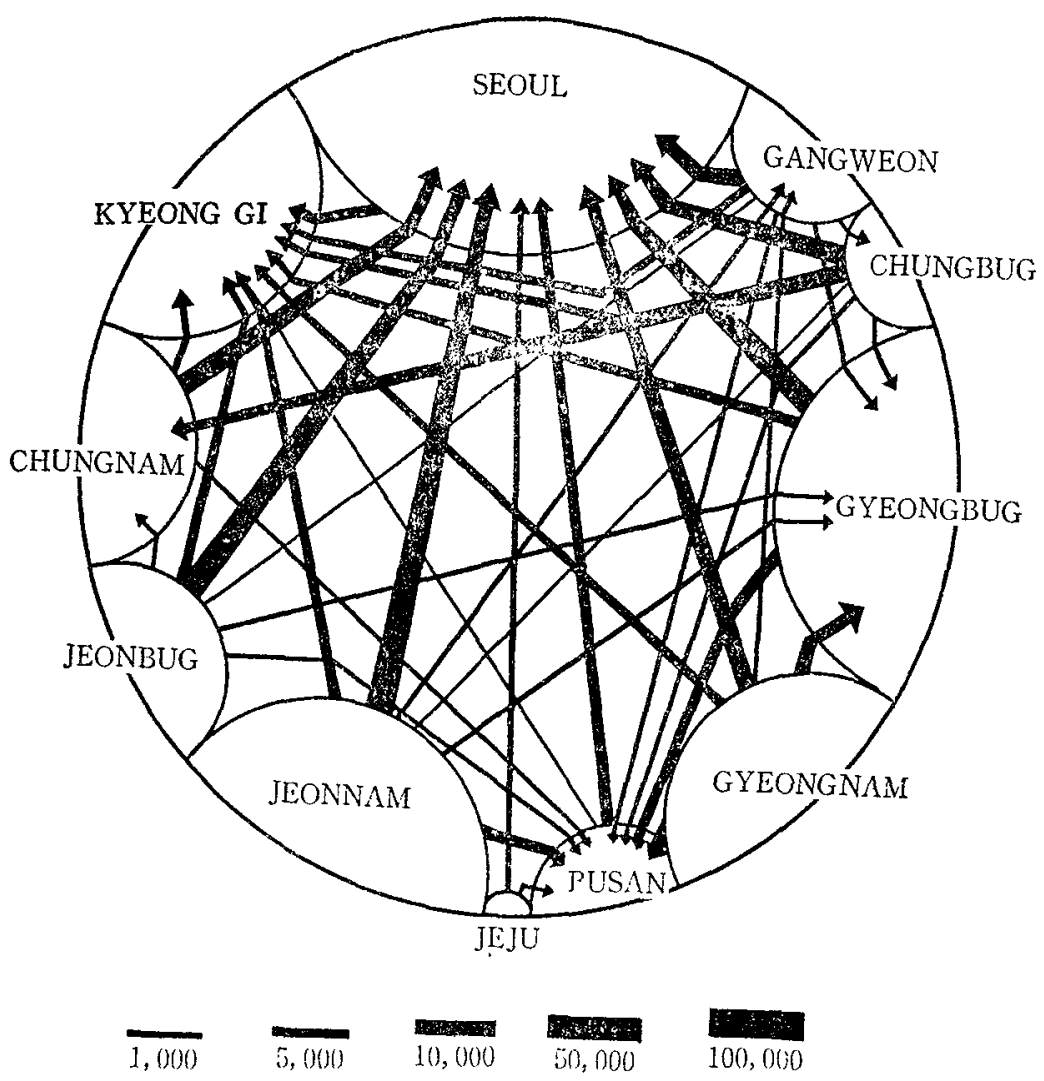

*The areas bounded by arcs indicate the comparative sizes of provincial populations.

Source:Lee(1973:16)

As for urban inmigration, Pusan, the second biggest city in Korea, repeats Seoul's experience and even shows a more rapid population growth rate than Seoul during the first half of the 1970's. In all, the metroplitan provinces of Seoul and Pusan gained net migrants of 5.7 million in 1961 75. A summary table(Table 3) based on the three population census undertaken in 1966, 1970 and 1975 tells that the two metropolitan provinces experienced 4.4 times inmigration and, on the contrary, 0.8 times outmigration volume compared with the nonmetropolitan provinces. Accordingly, these trends bring about a positive net migration rate of 11.5 per hundred residents for Seoul and Pusan, and a negative net migration rate of 3.3 for the nonmetropolitan provinces. As such, Seoul and Pusan gain 291.4 inmigrants for every 100 outmigrants, while the non-metropolitan provinces merely gained 54.8.

The predominant urban orientation, as found in Korean internal migration patterns, emp- 
Fig 2: Pattern of Net Migration in Seoul: 1961 66 and 1970 75*
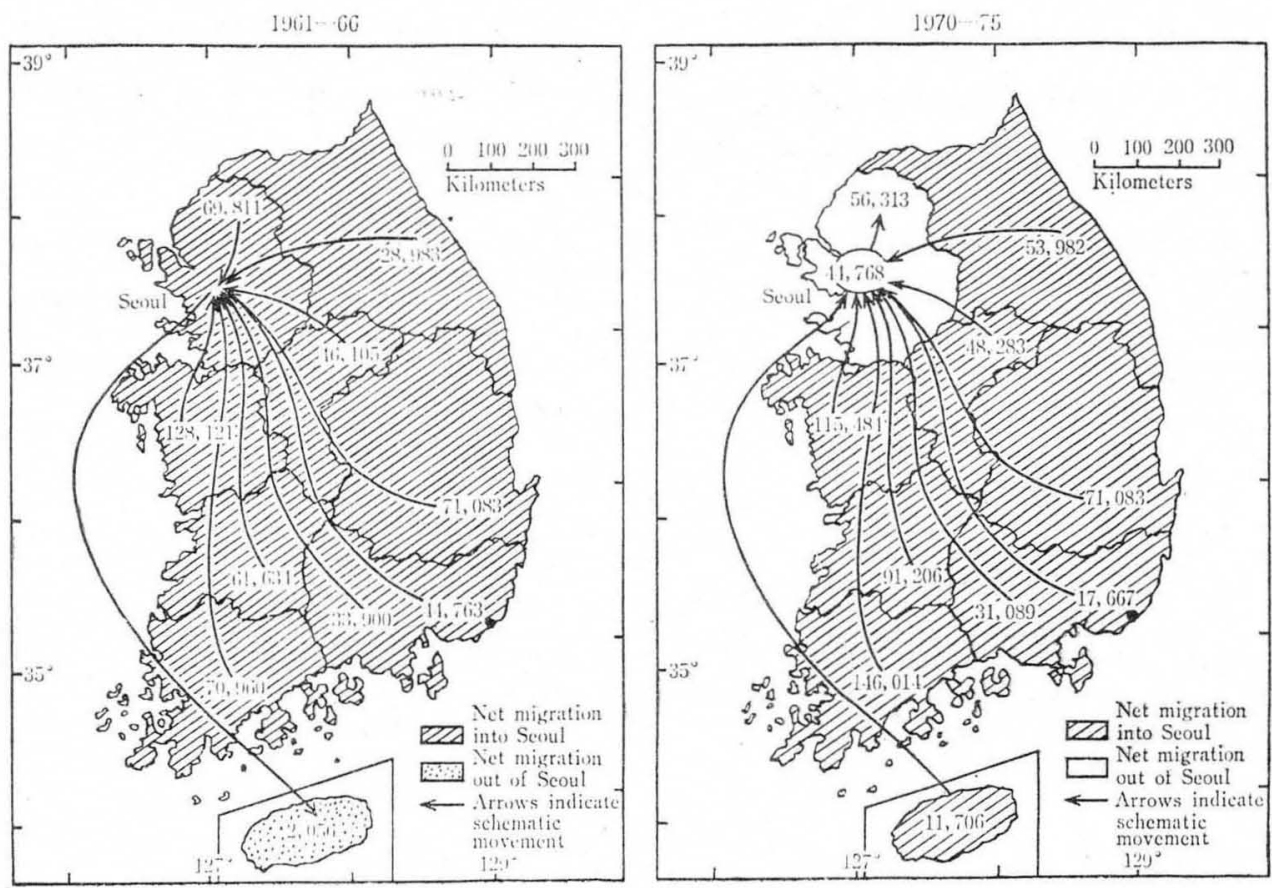

*The diagram for 1961 66 was adapted from Cho(1973) and the data for 1970 75 are from 1975 Population and Housing Census of Korea.

Table 3. Migration status ratios for Seoul and Pusan metropolitan areas and the other provinces, $1961 \sim 75$

\begin{tabular}{|c|c|c|c|c|c|c|c|c|}
\hline \multirow[b]{2}{*}{ Migration status ratio } & \multicolumn{2}{|c|}{$1961 \sim 66$} & \multicolumn{2}{|c|}{$1966 \sim 70$} & \multicolumn{2}{|c|}{$1970 \sim 75$} & \multicolumn{2}{|c|}{$1961 \sim 75$} \\
\hline & $\begin{array}{c}\text { Seoul \& } \\
\text { Pusan }\end{array}$ & $\mid \begin{array}{c}\text { Other } \\
\text { Provinces }\end{array}$ & $\begin{array}{l}\text { Seoul \& } \\
\text { Pusan }\end{array}$ & $\begin{array}{c}\text { Other } \\
\text { Provinces }\end{array}$ & $\begin{array}{l}\text { Seoul \& } \\
\text { Pusan }\end{array}$ & $\begin{array}{c}\text { Other } \\
\text { Provinces }\end{array}$ & $\begin{array}{l}\text { Seoul \& } \\
\text { Pusan }\end{array}$ & $\mid \begin{array}{c}\text { Other } \\
\text { Provinces }\end{array}$ \\
\hline $\begin{array}{l}\text { Outmigrants per } 100 \\
\text { residents in province }\end{array}$ & 4.8 & 5 & 5.1 & 8.7 & 7. & 8. 3 & 6.0 & 7.3 \\
\hline $\begin{array}{l}\text { Inmigrants per } 100 \\
\text { residents in province }\end{array}$ & 16.8 & 2.5 & 20.3 & 4.0 & 15.8 & 5.4 & 17.5 & 4.0 \\
\hline $\begin{array}{l}\text { Net migrants per } 100 \\
\text { residents in province }\end{array}$ & 12.0 & -2.5 & 15.2 & -4.7 & 8.4 & -2.9 & 11.5 & -3.3 \\
\hline $\begin{array}{l}\text { Inmigrants per } 100 \\
\text { outmigrants }\end{array}$ & 347.4 & 50. & 400.0 & 46.4 & 212.4 & 65.6 & 291.4 & 54.8 \\
\hline
\end{tabular}

Sources: EPB, 1966, 1970, 1975 Population and Housing Ceusus of Korea.

hasizes the primacy that Seoul, the capital city of the Republic, has enjoyed throughout its history. While absorbing 63\% of urban inmigrants in the years of $1961 \sim 66$, almost coincident with the time-span of the ambitious first 5-year economic development plan(1962 66) which was undertaken by the central government of Korea, Seoul turned out to be 
one of the best examples of overurbanization or hyperurbanization ${ }^{23}$ the world over, as referred to in Table 4. Seoul has never failed to maintain her primacy in the national urban hierarchy, despite being observed to have a relative decrease in the ratio of absorbing urban-oriented migrants. Consequently, it brought about the situation that one out of five Koreans resides in the municipal boundary of Seoul in the late 1970's.

Table 4. Intercensal population growth rate (percent) by area, 1960 75

\begin{tabular}{c|r|r|r|r}
\hline \hline & $1960 \sim 66$ & $1966 \sim 70$ & $1970 \sim 75$ & $1960 \sim 75$ \\
\hline Urban & 5.8 & 7.1 & 5.4 & $6.0 \%$ \\
Seoul & 7.6 & 9.9 & 4.4 & $7.1 \%$ \\
Pusan & 3.5 & 7.1 & 5.4 & $5.8 \%$ \\
Rural & 1.3 & -1.9 & +0.0 & $+0.0 \%$ \\
Town & 2.7 & 1.8 & 5.3 & $3.3 \%$ \\
\hline All areas & 2.7 & 1.9 & 2.0 & $2.2 \%$ \\
\hline
\end{tabular}

"Urban" is defined the area administratively designated as city, having a population of 50,000 and more, and "Rural" indicates non-urban area. Town is defined the agglomerated settlement administratively designated as Eup, having a population of $20,000 \sim 50,000$.

Sources: EPB, 1966, 1970, 1975 Population and Housing Census.

\section{Who moves:}

Age selectivity appears remarkable in Korean internal migration which took place from 1961 to 75 : the productive age groups of $10 \sim 39$ were more mobile than the other age-specific groups (Table 5). In particular, the age groups of 10 19 and 20 29 accounted for the majority of all migrants. Specifically speaking, the age group of 10 19 was more mobile in migration flow destined to urban sectors, but less mobile in its flow to rural sectors. In comparison, the age groups of $20 \sim 29$ and $30 \sim 39$ were active in both streams of rural and urban inmigration, as seen in Figure 3.

A high degree of mobility shown in the young age group of $20 \sim 29$ may be attributed to the fact that they are involved in first job-seeking, compulsary military service, education and training, and marriage. In detail, the age group of $10 \sim 19(31.0 \%)$ is the most mobile one in rural-to-urban migration stream, followed by the next most mobile group of $20 \sim 29$ (29.6\%), as it happened in 1961 75. And in urban-to-rural migration in the same period as above, the age group of $20 \sim 29(34.1 \%)$ is the most mobile with the second most mobile

(2) Hyperurbanization is defined as implying a doubling rate in urban population of at least twenty years, and, accordingly, showing an urbanization rate of 3.5 per cent or more per annum. The concept is more or less conceived to describe a prolonged condition of rapid urban growth producing strains and tensions in social system. John Friedmann (1973:91). 
Table 5. Age-specific compositions of migrants by migration direction in $1961 \sim 75$

\begin{tabular}{|c|c|c|c|c|c|c|c|c|c|c|}
\hline \multirow{2}{*}{ Age group } & \multirow{2}{*}{$\begin{array}{c}\text { Urban- } \\
\text { to- } \\
\text { Urban } \\
(1)\end{array}$} & \multirow{2}{*}{$\begin{array}{l}\text { Rural- } \\
\text { to- } \\
\text { Urban } \\
\text { (2) }\end{array}$} & \multirow{2}{*}{$\left|\begin{array}{c}\text { Urban } \\
\text { inmig- } \\
\text { ration } \\
(1)+(2)\end{array}\right|$} & \multicolumn{2}{|c|}{$\begin{array}{c}\text { Urban } \\
\text { inmigration }\end{array}$} & \multirow{2}{*}{$\begin{array}{c}\text { Urban- } \\
\text { to- } \\
\text { Rural } \\
(3)\end{array}$} & \multirow{2}{*}{$\begin{array}{c}\text { Rural- } \\
\text { to- } \\
\text { Rural } \\
(4)\end{array}$} & \multirow{2}{*}{$\left|\begin{array}{c}\text { Rural } \\
\text { inmig- } \\
\text { ration } \\
(3)+(4)\end{array}\right|$} & \multirow{2}{*}{$\begin{array}{l}\text { All } \\
\text { migrants }\end{array}$} & \multirow{2}{*}{$\begin{array}{c}\text { All } \\
\text { Koreans } \\
\text { in } 1970\end{array}$} \\
\hline & & & & Male & Female & & & & & \\
\hline $5 \sim 9$ & 12.7 & 10.3 & 11.6 & 13.3 & 11.7 & 13.9 & 14.6 & 14.3 & 12.2 & 14.4 \\
\hline $10 \sim 19$ & 22.9 & 34.1 & 28.2 & 25.4 & 22.7 & 17.2 & 21.8 & 19.9 & 26.2 & 23.8 \\
\hline $20 \sim 29$ & 27.4 & 29.6 & 28.8 & 24.8 & 33.0 & 31.0 & 28.7 & 29.6 & 28.7 & 15.0 \\
\hline $30 \sim 39$ & 20.3 & 14.3 & 17.5 & 22.0 & 16.4 & 22.1 & 17.4 & 19.3 & 17.9 & 12.9 \\
\hline $40 \sim 49$ & 8.6 & 5.7 & 7.2 & 8.5 & 7.2 & 8.1 & 8.6 & 8.4 & 7.5 & 8.8 \\
\hline $50 \sim 59$ & 4.8 & 3.3 & 4.1 & 3.9 & 4.9 & 4.5 & 5.0 & 4.8 & 4.3 & 6.0 \\
\hline Over 60 & 3.3 & 2.7 & 3.0 & 2.1 & 4.1 & 3.2 & 3.9 & 3.6 & 3.2 & 5.5 \\
\hline Total & 100.0 & 100.0 & 100.0 & 100.0 & 100.0 & 100.0 & 100.0 & 100.0 & 100.0 & 100.0 \\
\hline
\end{tabular}

Sources: EPB, 1966, 1970, 1975 Population and Housing Census of Korea.

age group of $30 \sim 39(22.1 \%)$. One interpretation is that young labor force yet to be trained moves from rural areas in an attempt to find jobs and/or educational opportunities in either big cities or booming industrializing cities. Some of them fail to find jobs and, after a while, may decide to return to the rural sector in their twenties or thirties. As for the sexual composition of urban inmigrants in regard to age-specific composition, the most mobile age group for men is the age group of 10 to 19 , while that for women is at the ages of $20 \sim 29$, as seen in Figure 4 . A reason for the latter, if other things are constant, may be attributed to the fact that, according to Korean custom, women should be in more frequent move to formate a household by marriage than their sexual counterparts.

Educational selectivity is another predominant feature in the migration stream. Migration studies more often than not indicate that the more educated, the more mobile. The Korean experience is no exception to the case, as seen in Figure 5. Both men and women manifest themselves in a significant association between geographical mobility and the educational attainment of junior high school and over. What is more, educational selectivity can be borne out in regard to migration directions. As seen in Table 6, urban orientation of college-educated migrants is much higher in the urban-to-urban flow $(23.8 \%$ and $23.2 \%$ in the case of male migrants in 1966 70 and 1970 75, respectively); compared with rural-to-urban flow $(7.8 \%$ and $7.9 \%$ in the same accounts made above), rural-to-rural flow (6.8\% and 7.3\%) and urban-to-rural flow (17.7\% and 16.0\%).

A matter worthy of note is the fact that there is a considerably high percentage of college-educated male migrants in urban-to-rural flows. At a first glance, it may be conceived as incompatible with the popular pattern of educational selectivity in city-wise migration. 
Fig 3: Age-specific structures of urban-and rural-inmigrants in $1961 \sim 75$, and all Koreans in 1970

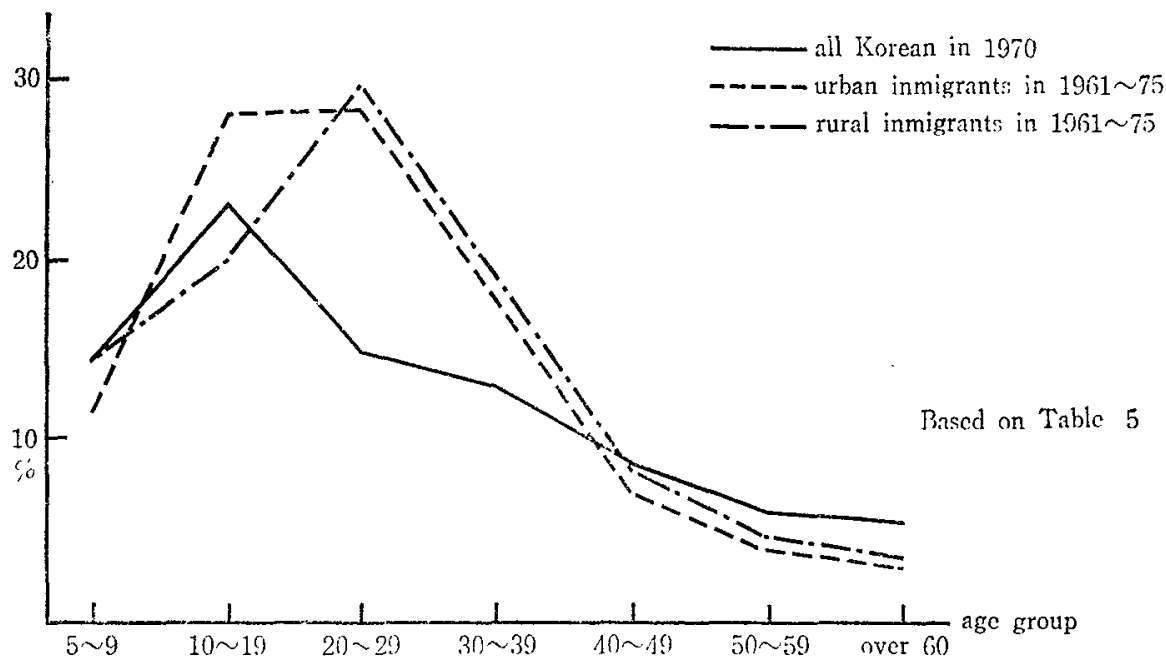

Fig. 4: Age-specific structures of urban inmigrants in $1961 \sim 75$ by sex, and all Koreans in 1970

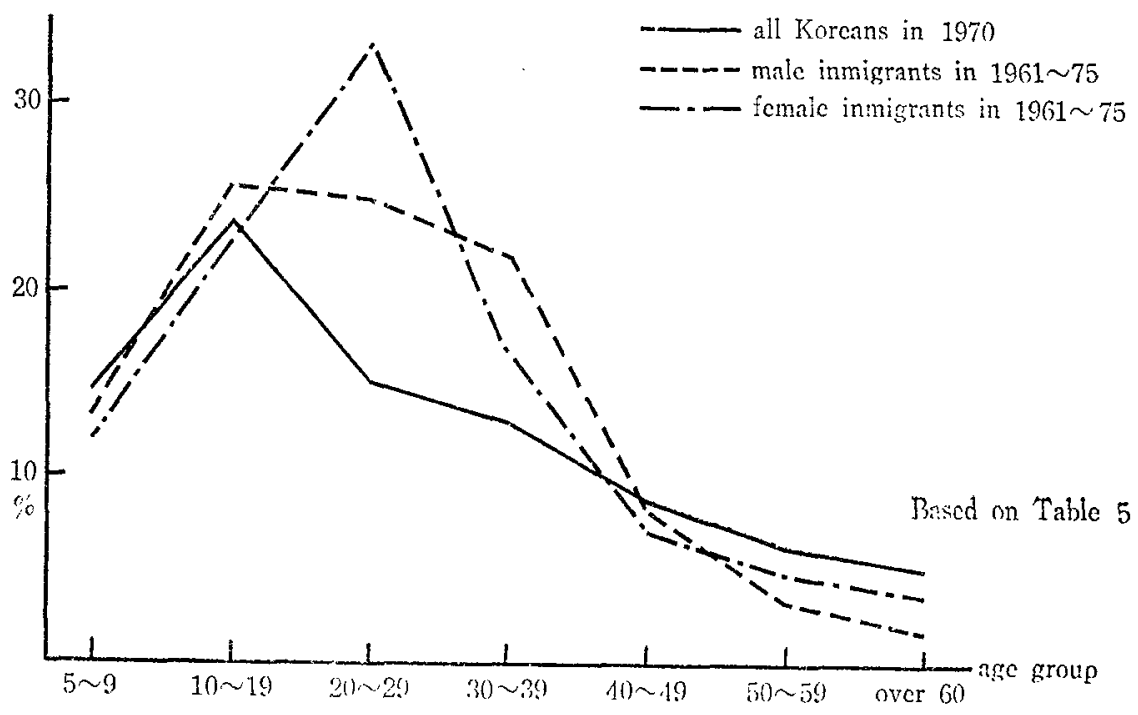

Two probable reasons can account for this: First, college graduates might exhibit residential mobility to suburban areas within metropolitan regions, of which some parts still belong to rural areas according to the current areal classification for administative purposes. Second, skilled labor forces having college degrees might voluntarily move to or be requested by the multi-plant companies headquartered at big cities to move to newly emerging industrial complexes located in remote areas. Bureaucrats and teachers in the postion of civil servants who move into rural areas may also belong to the latter category ( $Y u, 1978: 123)$.

As for job selectivity, it is not as much applicable to the internal migration of Korea 
Table 6. Proportions of college-educated ones to total volume(\%) of migrants by migration direction and sex, in 1966 70 and 1970 75

\begin{tabular}{c|c|r|r|r}
\hline & \multicolumn{2}{|c|}{$1966 \sim 70$} & \multicolumn{2}{|c}{$1970 \sim 75$} \\
\cline { 2 - 5 } Mear & Male & Female & Male & Female \\
\cline { 2 - 5 } & 23.8 & 8.6 & 23.2 & 9.1 \\
Urban-Urban & 16.7 & 6.9 & 15.9 & 4.4 \\
Urban-Seoul & 2.2 & 0.6 & 2.3 & 0.4 \\
Urban-Pusan & 7.8 & 4.5 & 7.9 & 1.7 \\
Rural-Urban & 3.9 & 3.7 & 4.3 & 0.8 \\
Rural-Seoul & 0.7 & 0.7 & 0.7 & 0.1 \\
Rural-Pusan & 17.7 & 4.7 & 16.0 & 5.4 \\
Urban-Rural & 6.8 & 0.9 & 7.3 & 1.2 \\
Rural-Rural & &
\end{tabular}

Sources: Economic Planning Board, 1970 and 1975 Population and Housing Census.

as educational selectivity, as seen in Figure 6 and Table 7 . Skilled workers such as professionals, technicians, administrators and business managers, and office workers amount to $19.4 \%$ in cities and $4.5 \%$ in rural areas out of their respective employed labor forces. These figures can be taken to refute job selectivity: a proportion (19.4\%) of the skilled labor force to employed labor force residing in urban areas to be joined by rural outmig-

Fig. 5: Educational attainment of urban inmigrants in $1966 \sim 75$ by sex and all Koreans in 1970

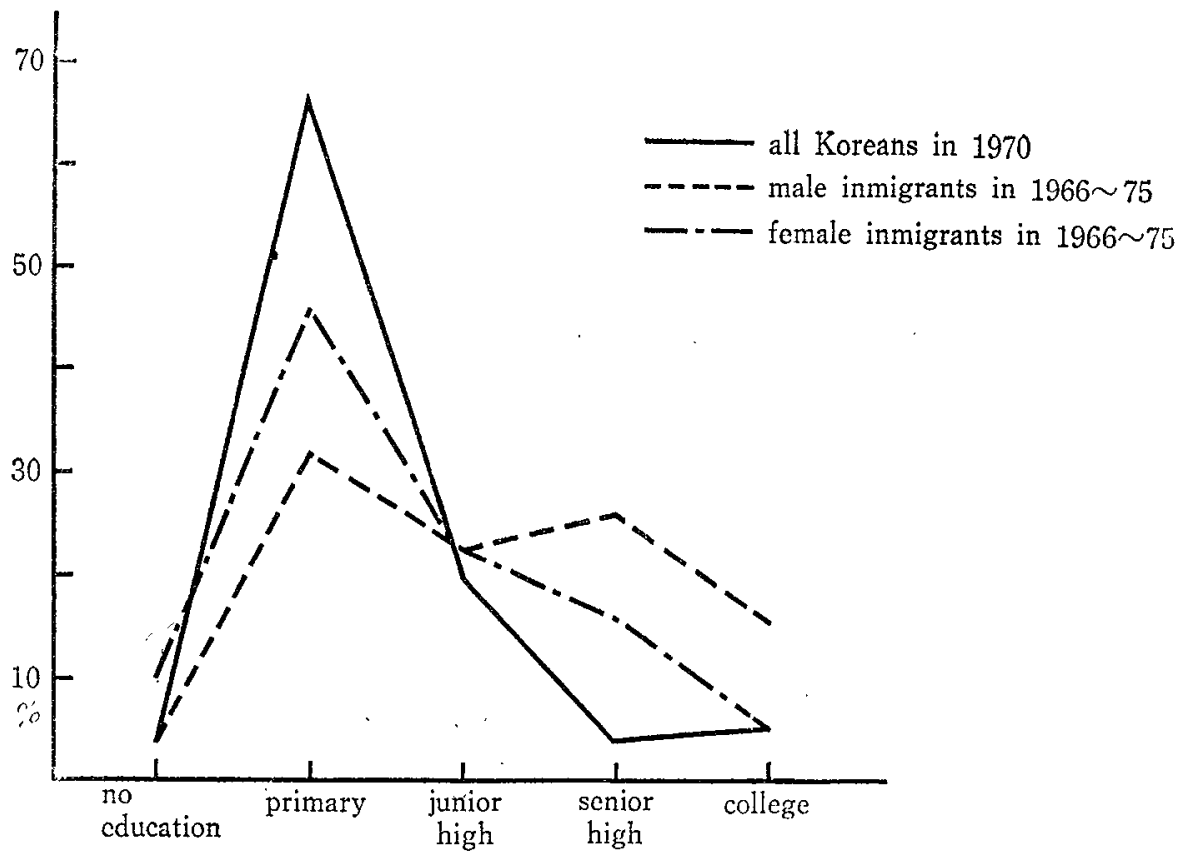

Sources: EPB, 1970 and 1975 Population and Housing Census. 
Table 7(a). Proportions of employed migrants by job category migration direction and sex, 1965 1975

\begin{tabular}{l|r|r|r|r|r|r}
\hline \multirow{2}{*}{ Job categories } & \multicolumn{5}{|c}{ Migrants in $1965 \sim 1975$} \\
\cline { 2 - 7 } & \multicolumn{2}{|c|}{ Rural to urban migration } & \multicolumn{2}{c}{$\begin{array}{c}\text { Urban to rural } \\
\text { migration }\end{array}$} \\
\cline { 2 - 7 } & Male & Female & Total & Male & Female & Total \\
\hline Professional, technical and related workers & 4.1 & 2.4 & 3.5 & 10.6 & 9.5 & 10.3 \\
Administrative and managerial workers & 0.8 & 0.1 & 0.5 & 1.4 & 0.0 & 0.9 \\
Clerical and related workers & 9.9 & 5.5 & 8.2 & 11.0 & 3.6 & 8.4 \\
Sales workers & 16.1 & 10.7 & 13.9 & 10.4 & 9.8 & 10.2 \\
Service workers & 9.2 & 31.6 & 18.0 & 7.4 & 27.7 & 14.6 \\
Agricultural and related workers & 3.6 & 2.6 & 3.2 & 23.5 & 34.2 & 27.3 \\
Production and other workers & 52.0 & 47.0 & 50.0 & 33.1 & 15.1 & 26.7 \\
Unclassified & 4.3 & 0.1 & 2.7 & 2.6 & 0.0 & 1.7 \\
\hline & 100.0 & 100.0 & 100.0 & 100.0 & 100.0 & 100.0 \\
& $(\%)$ & $(\%)$ & $(\%)$ & $(\%)$ & $(\%)$ & $(\%)$ \\
\hline Total in Number(1,000 Persons) & 982.5 & 637.4 & $1,619.9$ & 284.0 & 165.5 & 440.5 \\
\hline
\end{tabular}

Sources: Economic Planning Board, 1970 and 1975 Population and Houseing Census.

Table 7(b). Proportions of employed non-migrants by job category and sex, 1970

\begin{tabular}{l|r|r|r|r|r|r}
\hline \multirow{2}{*}{ Job categories } & \multicolumn{5}{|c}{ Non-migrants in 1970 } \\
\cline { 2 - 6 } & \multicolumn{3}{|c|}{ Urban areas } & \multicolumn{3}{|c}{ Rural areas } \\
\cline { 2 - 6 } & Male & Female & Total & Male & Female & Total \\
\hline Professional, technical and related workers & 5.8 & 4.7 & 5.5 & 2.4 & 0.9 & 1.9 \\
Administrative and managerial workers & 2.8 & 0.3 & 2.1 & 0.4 & 0.0 & 0.3 \\
Clerical and related workers & 13.5 & 7.7 & 11.8 & 3.4 & 0.7 & 2.3 \\
Sales workers & 19.0 & 20.4 & 19.4 & 4.5 & 5.1 & 4.7 \\
Service workers & 7.3 & 27.3 & 12.9 & 2.5 & 3.8 & 3.0 \\
Agricultural and related workers & 9.9 & 8.3 & 7.3 & 72.6 & 81.4 & 76.0 \\
Production and other worker & 43.0 & 31.0 & 39.6 & 13.3 & 7.8 & 11.2 \\
Not adequately described & 1.6 & 0.3 & 1.2 & 0.8 & 0.1 & 0.5 \\
Unclassified & 0.2 & 0.1 & 0.2 & 0.1 & 0.0 & 0.0 \\
\hline \multicolumn{1}{c|}{ Total } & 100.0 & 100.0 & 100.0 & 100.0 & 100.0 & 100.0 \\
\hline Total in Number(1,000 Persons) & 2,683 & 1,060 & 3,742 & 3,895 & 2,515 & 6.411 \\
\hline
\end{tabular}

Source: Economic Planning Board, 1970 Population and Housing Census.

rants is higher_than that (12.2\%) of skilled labor force out of employed workers in migration. In support of the above discussion, a ratio (19.6\%) of the skilled labor force to employed labor forces in urban-to-rural move is far higher than that (4.5\%) of the skilled labor force to employed workers of rural areas in residence (Yu, 1978:125).

The negative job selectivity in rural-to-urban migration can be elaborated further. Two 
Fig 6: Occupational distribution of urban inmigrants in $1966 \sim 75$ by sex, and all Koreans in 1970

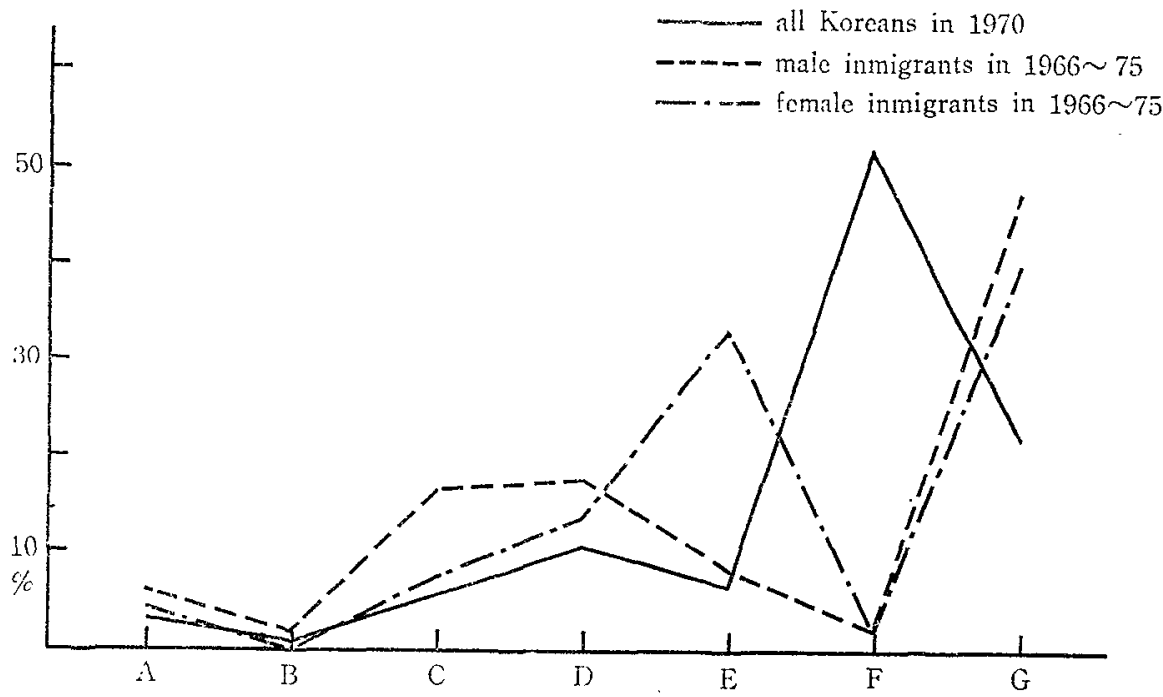

A: Professional, technical and related workers

B: Administrative and managerial workers

C: Clerical and related workers

D: Sales workers

E: Service workers

F: Agricultural and related workers

G: Production and other workers

Sources: EPB, 1970 and 1975 Population and Housing Census.

job categories of drivers, manual and related workers, and sales workers account for $52.0 \%$ and $16.1 \%$ out of employed male workers in the migration flow, respectively. As for female migrants, $78.6 \%$ of them are destined to be engaged in drivers, manual and related jobs $(47.0 \%)$, and service jobs $(31.6 \%)$ in urban areas. Regardless of male or female migrants, they are common in terms that they would have difficulty getting employed in modern sectors in cities because of their low educational attainment and poor preparedness for urban life.

More often than not, these male workers are reduced to low-status, low-skilled and low-pay job opportunities such as construction and manual jobs, peddlers, janitors and so on. Likewise, the job market for women is no more promising than male migrants. Many of them are engaged in "sweat" jobs such as those found in weaving and clothing factories, electronics companies, and the like. What is worse, a considerable number of young female migrants have no choice but to take notorious "underground" jobs such as massagers and prostitutes. In due course, the apparent polarization of urban job opportunities between modern and traditional sectors, typical for developing countries is getting 
worse rather than being converged, so long as an unceasing stream of yet-to-be urbanized labor force flow into big cities, and find it difficult to secure jobs in modern sectors and, even if possible, it would take much time to find them.

\section{Why they move}

Migration causes have received greater attention from concerned academicians and policy makers. A few studies have been filed with special reference to the case of recent Korea, and they easily lend themselves to two different kinds of studies varying with the perspective they adopt. One is the rigorous statistical approach designed to identify migration causes by making use of objective, quantitative variables largely in economic terms and partly in geographical terms. The other goes on the basis of social surveys aimed at the identification of socio-psychological and economic motives hidden behind the decision-making and action-taking of migration. The two research styles must be of complementary use between each other to answer the question as to why people move.

A quantitative study by regression analysis (Kim, 1976) came to the conclusion that migration volume in the case of Korean migration in $1966 \sim 70$ is significantly associated with wage level and job opportunities available in the destination places, and transportation distances: between origins and destinations. Put specifically, male migrants in the age group of $39 \sim 44$ are found to show more sensitive response to wage level, job opportunity of the destination places, and moving costs than the age group of $15 \sim 29$. But both groups are common in that the variable of job opportunity in the destination places is proved more significant than that of wage level in the former. On the other hand, the variables of job opportunity and wage level observed in the origin places appear insignificant in explaining the internal migration.

As far as the "push-pull theory" is concerned, these results suggest that "pull" theory is more valid than "push" theory in the Korean case. In other words, it seems likely that prosperous urban economies attract rural migrants to a greater extent than rural economies seemingly in stagnation. The same study also reveals that female inmigrants in the ages of $15 \sim 29$ respond more sensitively to job opportunity and wage level in Seoul than their sexual coounter-parts in the same age group. Also female migrants in the age group of $30 \sim 44$ are known to conceive wage levels in the destination and transportation distance to Seoul as being important in their decision-making for migration.

On other hand, attitude surveys(Table 8) were undertaken to examine motivation leading to migration into Seoul. Regardless of migration units by either household or single, more 
Table 8. Mobility motives by inmigrants to Seoul

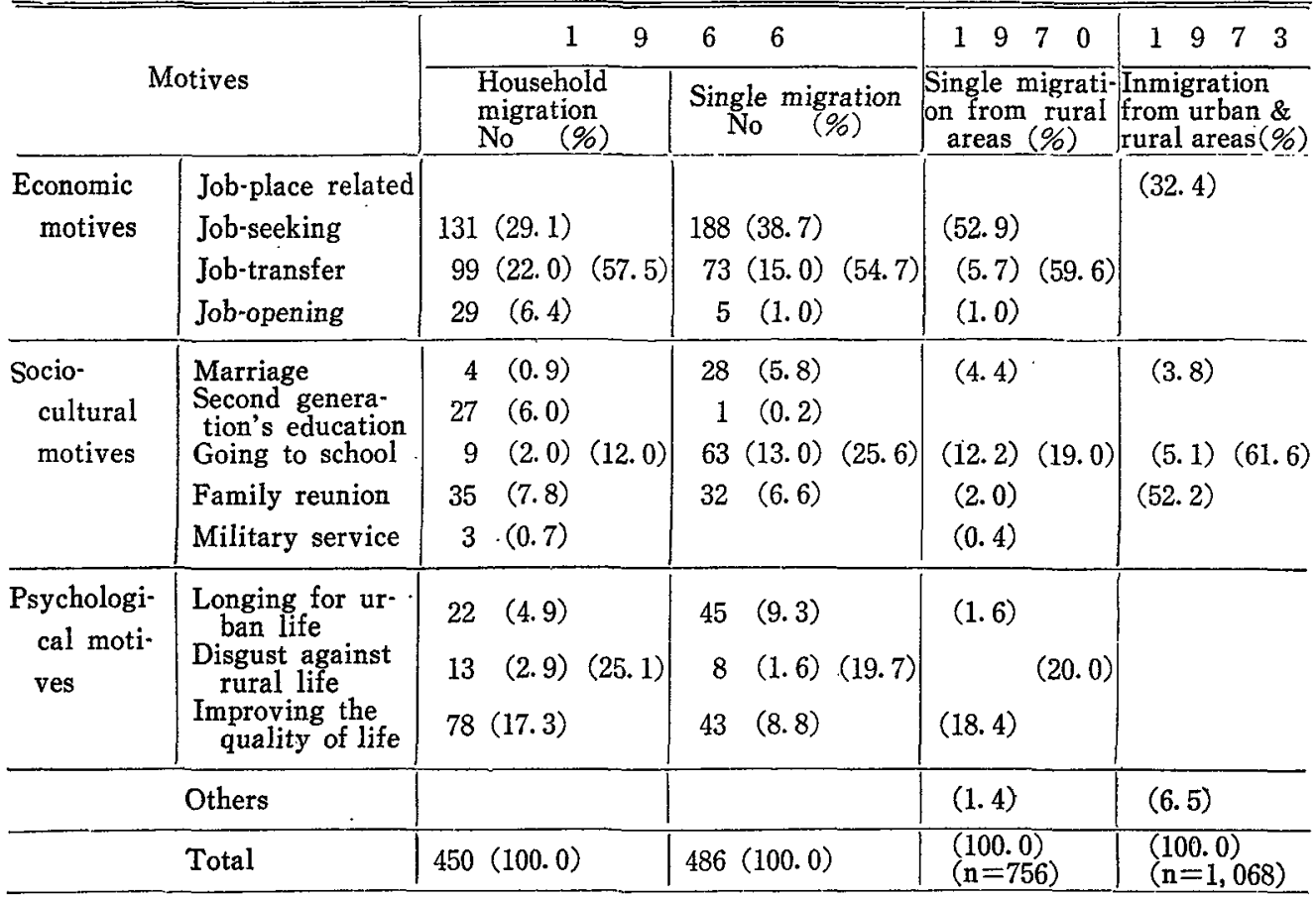

Source: Yoon (1976:21)

than half of the Seoul inmigrants perceive economic motives such as job-seeking, job-opening and job-transfer as the most important factors in their migration decision. A considerable number of migrants move to take advantage of socio-cultural amenities concentrated in Seoul. The most attractive among them is educational opportunity in Seoul which has enjoyed a comparative advantage over those in the rest of the country. ${ }^{(3)}$ In this connection, for instance, university study at a few distinguished higher education institutions located in Seoul is conceived as a guarantee for upward social mobility. Under these circumstances, it is no wonder at all that 13 percent of single migrants in 1966 moved to take advantage of better educational opportunities in Seoul.

Psychological motives comprise three sub-categories: (1) a pull factor of "longing for urban life" as found in Seoul; (2) a push factor of "disgust for rural life" looming large in rural areas; and (3) the third factor of "improving the quality of life" seemingly intermixed with the pull and push factor. Of the Seoul inmigrants, 17.3 per cent, who identify "improving the quality of life" as an overriding determinant in the decision-

(3) As of 1975 , there are 36 universities and 46 graduate schools in Seoul out of the national totals of 72 and 82 , respectively. 
making of migration, may be taken as people who feel pushed by declining . rural economies and, at the same time, pulled by thriving urban economies at their destinations. In most cases, they vaguely believe in, before their moves, greater availability of job opportunities in Seoul. But it poses another question as to whether perceived chances in Seoul have been taken into effect after their moves. The "push" factor of "disgusting for out-migrating places" is recorded to be fairly negligible among psychological motives. This outcome squares with the finding provided by the quantitative study quoted above. Both of the findings conclude that the "pull" theory makes more sense than the "push" theory, as far as Seoul-ward migration is concerned.

There is the other empirical evidence (Lim, 1976:89) in support of the "pull theory" applicable to urban inmigration. It confirms the fact that rural people prefer urban life. Asked where they want to live in the future, senior high school students located in rural areas express a strong desire to live in cities. Their preferences are for small-and medium-sized cities $(47.1 \%)$ and big cities (25.0\%). Of the sampled interviewees, only 25 per cent want to remain in rural areas. The reasons why they prefer urban life include "active social life" (41.9\%), "better educational opportunities" (23.1\%), and "higher cultural amenities" (22.3\%), as found in cities.

\section{Summary}

(1) Urban orientation is predominant in the direction of Korean internal migration. This pattern contributed much to the explosive growth rate of urban population in $1961 \sim 75$.

(2) In urban orientation, big cities, in particular, Seoul, the capital city of the nation, turn out to be great recipients of migrants.

(3) The Seoul metropolitan region is undergoing wide-scale spatial reorganization such as suburbanization and the expansion of the urban field in her own right.

(4) As for age-specific characteristics of Korean internal migration during 1961 75, the younger, the more mobile. That is, there is observed selective migration in terms of age structure. This pattern, however, appears to a lesser degree in rural inmigration as against urban inmigration.

(5) There may also be noted educational selectivity in which the more educated are, the more mobile, in particular, in a direction toward urban sectors. As an exceptional case to this pattern, college-educated migrants are, to a great extent, found in the urban-to-rural migration flow. Their moves take place primarily due to job transfers within multi-location organizations, either public or private. For this reason, their moves seem unlikely to be 
permanient, but last no longer than 5 years.

(6) Job selectivity is not as much applicable to the internal migration of Korea as educational selectivity. What may account for this pattern is that many migrants attempt to realize upward occupational mobility by educating their second generation.

(7) In an aggregate sense, the economic factor is the prime cause as found in Korean internal migration. Since thriving urban economies attract migrants to a greater extent than they are pushed by relatively stagnant rural economies, the "pull" theory is more valid than the "push" theory in regard to the recent Korean experience.

(8) The rapid growth of the national economy has, for the past two decades, called for a great number of surplus labor from rural sectors. This public interest to a great extent has been matched by private interest in that every migrant attempts to achieve upward mobility in the socio-economic sphere.

(9) As a matter of fact, economic cause as the prime reason for migration is closely interrelated with social, psychological, and cultural factors mostly available in big cities. This is self-evident because economic factors stand in a circular causal relation with desirable, non-economic causes.

\section{Part II: Behaviors of inmigrants to Seoul}

The preceding discussion was made from the standpoint that is largely aggregative and macro-analytic in nature. Although reflecting social dynamics implied in internal migration, a macro-scopic approach as to how migration events occur leave a number of important questions unanswered. In this context, questions worthy of examination have to include: (1) By which evaluative process do individuals decide to migrate? (2) How does migration take place? (3) How do they adapt themselves to urban environments? And (4) to what extent do they achieve what they expect in urban sectors? In an effort to answer these questions, an alternative approach as an intermediate-scale analysis is called for to discuss behaviors of individual migrants. The approach is of use in learning about socio-economic mobility which rural migrants experience in urban circumstances. This attempt may be facilitated by focusing on rural migrants who have poured into those big cities predominantly preferred by active and potential Korean migrants.

What follows is concerned with the rural migrants who have moved into Seoul. Paying attention to Seoul is justified primarily because it is the capital city of Korea and has, for 
a long time, absorbed a great volume of migrants both from urban and rural sectors, as pointed out earlier. On this account, inmigrants to Seoul have received more attention than those to any other city from concerned policy-makers. And there exist qualified studies which have attempted to elaborate behavioral patterns with special reference to inmigrants to Seoul.

\section{Decision-making of migration}

There is little relevant, reliable information as to how inmigrants decide to move to Seoul. But it is a common understanding that all Koreans in every corner of the country long to live in Seoul where major social values are perceived as being concentrated. In fact, the phenomenal skewedness of various well-being indicators is observed in favor of Seoul, compared with the rest of the country. The spatial dualism is as eloquantly remarked as "the capital city and the Republic of Seoul", as France is nickamed as "Paris and the desert of France". The reality at issue that various societal values are concentrated in Seoul is represented in Table 9.

Under these circumstances, it cannot be overestimated that every potential migrant is well informed that Seoul is more thriving than any other urban center in Korea. This description has bearing on: (1) the overriding primacy of Seoul over other local urban economies in the national urban hierarchy, (2) a very low percentage of illiterates within the national population, and (3) the small size of the Korean territory, where distance friction does not present a difficult problem to overcome on the part of migrants.

Table 9. Share of Seoul in major economic indicators: 1976

\begin{tabular}{|c|c|c|c|}
\hline & $\begin{array}{c}\text { The } \\
\text { Nation(A) }\end{array}$ & Seoul(B) & $\mathrm{B} / \mathrm{A}(\%)$ \\
\hline $\operatorname{Area}\left(\mathrm{Km}^{2}\right)$ & 98,824 & 628 & 0.6 \\
\hline Population $(1,000)$ & 36,450 & 7,525 & 20.6 \\
\hline Gross national/urban products(billion won*) & 4,767 & 1,526 & 32.0 \\
\hline Per capita income $(1,000$ won $)$ & 624 & 960 & 153.8 \\
\hline No. of manufacturing firms & 22,787 & 5,988 & 26.2 \\
\hline Internal revenue(billion won) & 1,282 & 742 & 57.8 \\
\hline No. of corporations & 16,199 & 11,360 & 70.1 \\
\hline Total amount of saving(billion won) & 369 & 234 & 63.5 \\
\hline Total amount of loan(billion won) & 372 & 245 & 65.8 \\
\hline No. of market facilities & 640 & 252 & 49. 3 \\
\hline No. of medical doctors & 11,381 & 4,651 & 40.8 \\
\hline Tax payable income earners $(1,000)$ & 1,103 & 579 & 52.2 \\
\hline
\end{tabular}

*One U.S. dollar is equivalent to 610 won, to date.

Source: The National Chamber of Commerce, 1978. 
Nonetheless, people informed of Seoul's attractiveness do not necessarily move to Seoul. Since no study has ever been made comparing people informed of Seoul and, thereafter moved to Seoul, with those informed of Seoul, but having not moved as yet to Seoul, it is not possible to make any accurate judgement on the behavior of immigrants to Seoul. Even though their behaviors should be examined in such a comprehensive manner as indicated above, what has been disclosed thus far is the fact that information disseminated by relatives and friends concerning opportunities at the possible destination plays a greater role in the decision-making and action-taking of migration, as examined by many case studies concerning developing countries. (Shaw, 1975:92; Findley, 1977:15)

A study (Yoon, 1970:147) examines the role of information channels working on inmigrants to Seoul. As revealed by the study, four out of 10 inmigrants (Table 10) fall short of any information sources including family, relative and acquaintance before migration But this finding may not be applicable to the other types of migration by family-in-part and single, as eight out of such ten cases in both family-in-part and single migration depend on personal ties such as family, relatives and acquaintances, who have previously moved to Seoul, as information sources. On the contrary, one out of two cases in family migration dares move to Seoul without any personal tie.

Table 10. Migration channels by migration type

\begin{tabular}{|c|c|c|c|c|c|c|c|c|c|c|}
\hline \multirow[b]{2}{*}{ Migration channel } & \multicolumn{2}{|c|}{ Total } & \multicolumn{2}{|c|}{$\begin{array}{c}\text { Family } \\
\text { migration }\end{array}$} & \multicolumn{2}{|c|}{$\begin{array}{l}\text { Family- } \\
\text { in-part }\end{array}$} & \multicolumn{2}{|c|}{$\begin{array}{c}\text { Single } \\
\text { migration }\end{array}$} & \multicolumn{2}{|c|}{ Others } \\
\hline & No. & $\%$ & No. & $\%$ & No. & $\%$ & No. & $\%$ & No. & $\%$ \\
\hline Family & 329 & 14.8 & 167 & 10.9 & 124 & 40.8 & 37 & 9.5 & 1 & 2.0 \\
\hline Relatives & 657 & 29.5 & 478 & 30.8 & 264 & 25.7 & 116 & 29.7 & 4 & 7.8 \\
\hline Acquaintances & 355 & 15.9 & 148 & 9.6 & 22 & 8.8 & 162 & 41.4 & 23 & 45.1 \\
\hline None & 885 & 39.8 & 747 & 48.7 & 39 & 15. 7 & 76 & 19. 4 & 23 & 45.1 \\
\hline Total & $\left|\begin{array}{r}2,226 \\
(100 \cdot 0)\end{array}\right|$ & 100.0 & $\begin{array}{r}1,535 \\
(69.0)\end{array}$ & 100.0 & $\begin{array}{r}240 \\
(11.2) \\
\end{array}$ & 100.0 & $\begin{array}{r}391 \\
(17.6) \\
\end{array}$ & 100.0 & $\begin{array}{r}51 \\
(2.3)\end{array}$ & 100.0 \\
\hline
\end{tabular}

Source: Yoon (1970).

As for single migrants, decision-making to move is influenced by acquaintances (41.4\%), relatives (29.7\%), and family (19.5\%) in order. A qualitative study (Brandt, 1973) is interesting in the sense that it is intended to describe the behaviors of single migrants into Seoul in further detail. It classifies them into three categories: (1) "the boy or girl, usually not always from a poor household, who leaves or runs away from what he regards as an intolerable situation": (2) "those who leave home with the blessing or acquiescence of their families" and (3) "the sons and daughters of well-to-do rural and provincial 
families, who come to Seoul in order to continue their education or to fill some prearranged slot in business".

By comparison of these categories with Yoon's findings (1970), single migrants having no reliable information ( $19.4 \%$ of the total single migrants) belong mostly to the first group as classified by Brandt. He is quoted as saying that "they are committed to making their own way in Seoul and expect neither help from home nor a refuge there if they fail" (Brandt, 1973:7). On the other hand, the second and third groups fall into the single migrants who are furnished information by the family, relatives or acquaintances $(41.4 \%)$. The point being made in this connection is that information channels on the part of migrants serve in most cases as patrons ready to help those in finding urban homesites and, if possible, jobs. What have been discussed thus far leads to a conclusion that a chain migration mode is predominant in Seoul-wise population movement. The mode works to accelerate inmigration to Seoul with the help of family-like ties such as relatives and acquaintances.

As far as the migration process is concerned, a step-wise migration pattern is noticed in the inmigration stream to Seoul. Literature ${ }^{(4)}$ concerning migration patterns in developing countries indicates that a stepwise migration pattern appears popular particularly in ruralto-urban movement. The pattern takes place in such that migrants move from rural areas to small-sized cities, from small-sized cities to medium-sized cities, and at last, from mediumsized cities to big cities.

A sample survey (Barringer, 1974) finds that, of the inmigrants into Seoul under survey, 38.1 percent experience step-wise migration, whereas the rest come directly from places of origin. The step-wise pattern seems less frequent than what is found to be typical for many other developing countries. This observation is attributable to the fact that Korea is small in territorial size and, accordingly, the distance factor in migration is not significant. Otherwise, it is because the cost migrants have to pay for their move to Seoul is, by the estimation of opportunity cost, far less than what they might have paid for at other alternative urban destinations, as long as Seoul's economy works more vigorously than elsewhere.

What is more, there is no ethric segregation in Korea which is noted for homogeneity in culture, language and way of life. Accordingly, a theoretical assertion that social distances between places of origin and destination would likely inhibit direct flows is by no means applicable to inmigration to Seoul.

(4) Among others, see Breese (1968:83) and Shaw (1975:45-6). 


\section{Job mobility of the inmigrants}

A theoretical discussion (Thompson, 1972) contends that inmigrants into big cities usually become better-off, regardless of where their origins are. The point is made in that social costs the inmigrants incur at destinations and origins, particularly, of either small cities or rural areas is not their concern at all. The inmigrants do not take account of such social costs as increased congestion, greater trip distances and inner-city housing shortage to which they would contribute, when making their decision to move into big cities. It does not necessarily mean, however, that they would be free from urbanization costs they pay for on an individual basis. In this context, what follows focuses on how inmigrants to Seoul adjust themselves to urban life from the standpoint of occupational mobility.

At the outset, migrants to urban sectors attempt to have the quality of their lives improved in the socio-economic sphere. How much they achieve of what they aim at can be answered in part by how they feel about their living conditions after migration. $A$ number of case studies are available to this end. Barringer's (1974) finds that half of inmigrants to Seoul are satisfied with living conditions after migration. Of the surveyed migrants, 41.6 per cent feel "somewhat better" with after-the-move living condition, and 9. 4 per cent feel "much better", whereas one-third (33.5\%) do not feel any change in their living condition. On the other hand, a small portion expresses dissatisfaction with Seoul to the extent that 9.7 per cent feel "somewhat worse", followed by 5.8 per cent feeling "much worse". Despite the substantial presence of those who are frustrated with urban life in Seoul, it seems more likely that the inmigrants, to a significant degree, succeed in upward mobility by leaving rural areas and, thereafter, by participating in the thriving urban economy of Seoul.

From a temporal perspective, the inmigrants who feel "much better" or so are thought as those succeeded in achieving ones goal mostly over an intragenerational time-span. In the meantime, of the frustrated inmigrants who failed to take intragenerational mobility into effect, many may work hard to realize their achievement goal through their next generations, say, intergenerational mobility. The same study quoted above identifies the occupational mobility manifested by new migrants and native urbanites in Seoul over generational time-span, as shown in Table 11. It carries the categories of "father's occupation" (pre-migratory status for migrants only), "first occupation in the city", and "present occupation" which are made to demonstrate generational mobility of the Seoulite: The categories are presumed to say that differences between "father's occupation" and "first 
Table 11. Occupational mobility in Seoul

\begin{tabular}{|c|c|c|c|}
\hline Occupational category & Father's & First occupation & Present \\
\hline Occupation & occupation & First occupationa & occupation \\
\hline Survival & 12.6 & 27.5 & 5.0 \\
\hline Unemployed or unclassified & 12.3 & 16.4 & 4.0 \\
\hline Unskilled labor & 0.3 & 11.1 & 1.0 \\
\hline Primary & 65.7 & 2.4 & 1.4 \\
\hline Farmer-fisherman & 65.7 & 2.4 & 1.4 \\
\hline Secondary & 1.7 & 17.0 & 17.8 \\
\hline $\begin{array}{l}\text { Transportation, communication, } \\
\text { mining }\end{array}$ & 1.0 & 9.7 & 12.9 \\
\hline Skilled labor and crafts & 0.7 & 7.3 & 4.9 \\
\hline Tertiary & 20.0 & 53.1 & 75.8 \\
\hline Traditional & 11.0 & 19.6 & 31.3 \\
\hline Service & 0.4 & 1.6 & 10.3 \\
\hline Sales-merchants & 10.6 & 18.0 & 21.0 \\
\hline Modern & 9.0 & 33.5 & 44.5 \\
\hline Office-clerical workers & 3.0 & 11.3 & 12.7 \\
\hline Managerial & 2.4 & 12.1 & 15.7 \\
\hline Professional-technical & 3.6 & 10.1 & 16.1 \\
\hline Total & 100.0 & 100.0 & 100.0 \\
\hline
\end{tabular}

Source: Adapted from Barringer(1974).

occupation" imply intergenerational mobility, while those between "first occupation" and "present occupation" may be defined as intragenerational mobility.

As such, the highest proportion of the occupational category which father's generation was engaged in centers on the unemployed or unclassified. Occupations in the city for the first time are distributed in a unsettled manner: while the unemployment rate goes higher than ever before, a plurality of the surveyed lives on tertiary activities such as office-clerical workers $(11.3 \%)$, sales-merchants (18.0\%), managerial (12.1\%), and professional-technical $(10.1 \%)$ jobs. In the remainder, a polarization phenomenon arises between unskilled labor (11. 1\%) and skilled labor and crafts $(7.3 \%)$.

In contrast, the column "present occupation" in Table 11 addresses itself to the fact that the share of tertiary activities increases greatly in disproportion with a sharp rate-cut in unemployment. The proportional increase of tertiary activities may parallel to some extent qualitative, structural changes which accompany upward mobility from traditional or manual ones to modern service or professional sector.

- The extent to which the inmigrants get through intragenerational and intergenerational mobility in job opportunities is succinctly defined in Figure 7 . The figure is made on the 
Fig 7: Intra- and inter-generational occupational mobility

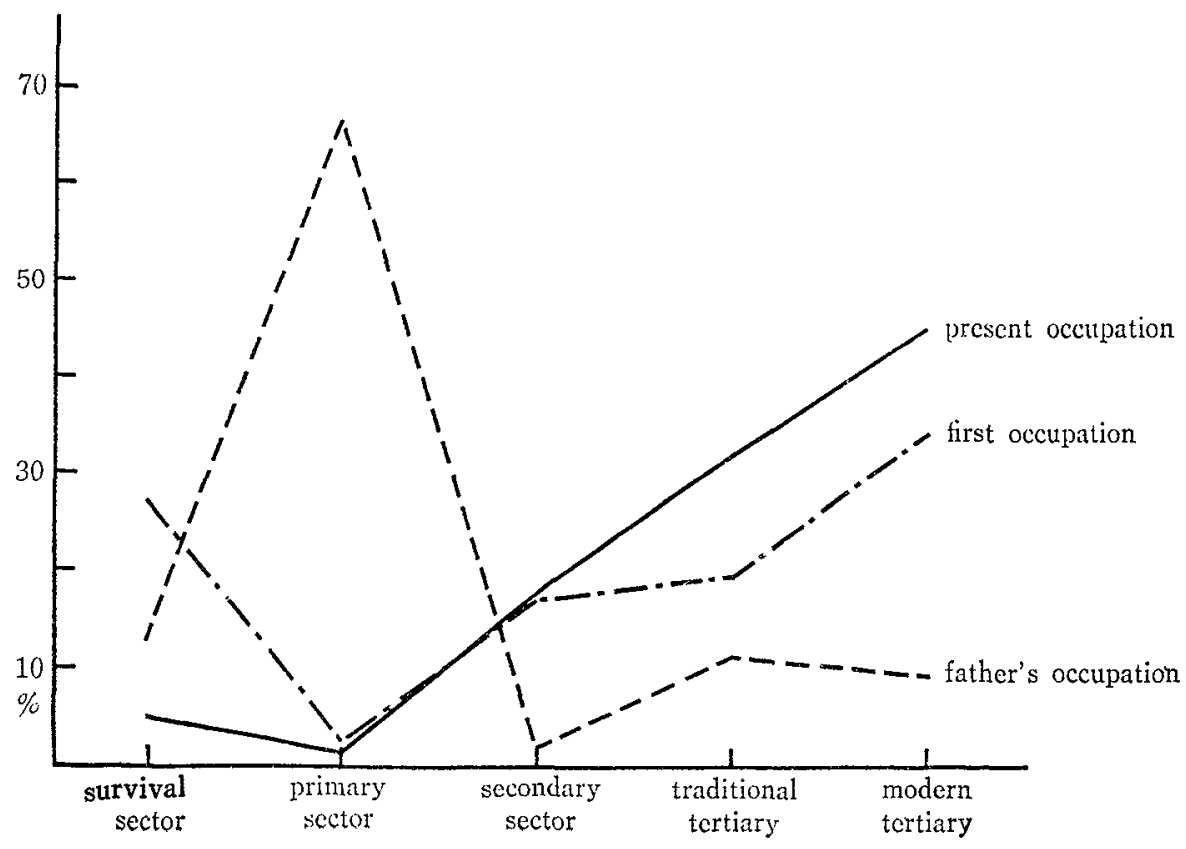

Sources: Based on table 11

basis of the data adapted from Barringer's to this writer's attempt: the occupational categories of Barringer are sectorally grouped into the primary, secondary, tertiary activities, and survival sector ${ }^{(5)}$ including the unemployed, unclassified and unskilled. Thereafter, tertiary activities may be divided into traditional and modern sectors. Figure 7 illustrates that the geographical mobility to Seoul parallels occupational transfers from the primary sector to the secondary or tertiary sector, within which development effect is also noticed in the move from the traditional sector to the modern one.

As for the individual standpoint of every urban inmigrant, however, it is more than difficult to achieve upward mobility. In particular, upward mobility within an intragenerational time-span is not readily attainable on the part of unskilled inmigrants. The difficulty is figured out to the extent that, i.e., professional jobs are continuously taken by those who

(5) Survival sector is defined as encompassing unemployed workers, handicraft workers, street traders and service workers, casual construction workers, and "underground" occupations, See Friedmann and Sullivan (1975:476), 
Table 12. Occupational mobility of family-heads before and after migration to Seoul, 1973

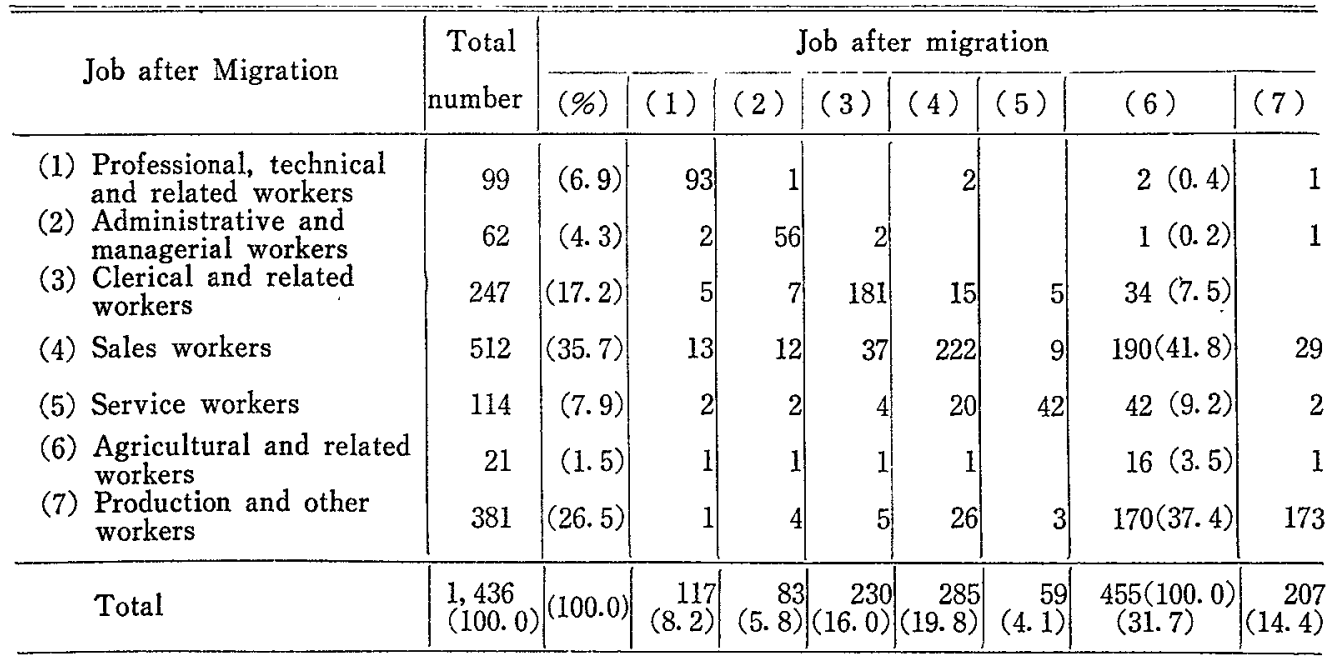

Source: Yoon (1975).

were professionals even before moving, as seen in Table 12. Such is the case for administrative and managerial workers, and clerical and related workers. In contrast, sales job are popular for those previously engaged in the former as well as those who were farmers before moving. Likewise, service and production jobs are feasible for low-skilled rural outmigrants.

Immediately after their move to Seoul, rural outmigrants of farming origin find easy access only to trifling jobs such as sales $(41.8 \%)$, and production and related ones (37.4 $\%)$, of which productivity is no better than in the agricultural sector. Specifically speaking, the jobs of sales and production are found, for the most part, in the individual-enterprise sector such as handicraft workers working on their own account, street traders, casual construction workers, and family-enterprise sector at trade and service establishments, and manufacturing workshops. The former includes traditional jobs such as small shop proprietors, salesmen in small businesses, garage mechanics, truck, bus, and taxi drivers, barbers, beauticians, and restaurant workers, and the latter comprises workers in various kinds of smallscale manufacturing such as bakeries, rice mills, noodleshops, shoe and leather-ware manufacturing, tailoring, carpentry, and metal work. (Friedmann and Sullivan, 1975)

As far as job mobility is concerned, young migrants draw considerable attention. This is because many of them are first job-seekers. Therefore, a closer discussion concerning the job mobility which young single migrants individually undergo would be of use in figuring out how social mobility takes place concurrently with city-ward mobility. Brandt's 
(1973) geared, more or less, to this end. His observation is intended to contrast the adjustment process of the inmigrants in success and failure. His criterion to judge the successful assimilation of migrants to city life is determined by whether they were able to find steady employment. As for young man without connections or special skills, the construction industry is available at best to them. But construction jobs are subject to frequent layoffs depending on business cycle, apart from limited availability temporally confined to non-winter seasons between March and November. In many cases, these circumstances coerce them to find alternatives such as "carrying heavy loads in the market place, pushing hand carts, running errands, or attaching oneself to a skilled worker or shop owner as an unpaid apprentice."

Because of poor job stability and growing dissatisfaction with their job environment, young migrants usually change jobs after six months of a year when they have established their networks and have looked over what the city has to offer. Worse yet, young migrants who fail to find jobs characterized by low-pay, low-status, and low-future prospects more often than not fall into underground jobs such as pimps, gangs, smugglers, black marketeers and so on.

However, there are some opportunities for unskilled young migrants to find steady job in firms characteristic of the modern sector, which pay higher wages than any traditional job sectors. Once they get job opportunity, they work hard to adapt themselves to the urban jobs. Success stories in this category are filed by Brandt (1973)

"Newly arrived village boys are often physically stronger, more docile, and willing to work for less than natives of Seoul, and, as a result, proprietors of small shops and labor intensive plants sometimes prefer them and even recruit in the countryside. If a country boy finds a job in a small firm that is growing, and if he is willing to work faithfully for years at low wages, his future is reasonably secure."

As for female inmigrants yet to be skilled, it is commonly understood that many of them in their teen's or early $20^{\circ} \mathrm{s}$ get into the city as live-in maids. There are accounts of bright scenes for job mobility on the part of female migrants: (Brandt, 1973:14)

"With practically no personal expenses she will usually be able to save enough in a year or eighteen months so that she can support herself while attending a vocational institute in order to learn hairdressing, wig making, machine knitting, or even taxi driving. Or she may find a job with an electronics firms or in a textile mill where the company will provide training. In two or three years, then, most girls who follow this route will have acquired a skill, a steady job, and some savings." 
However, fastidious urban circumstances often stand in the way rather than for the well-being of female migrants. Poor educational achievement and lack of preparedness for urban life make them vulnerable in achieving an amenable quality of their lives. If and when they fail to find job opportunities, one of alternative choices that they might possibly make is to get involved in one of various sordid aspects of the "entertainment" industry, if possible, only for a short time for transitory purpose. After a while, however, it becomes extremely difficult for them to turn a different kind of life.

Nevertheless, an interesting mode of behavior is found in the maladjusted female migrants who have fallen from desirable upward mobility. The mode says that many female migrants involved in entertainment jobs like bar girls or other miserable jobs seem rather unlikely to give up upward mobility. Although they fail to realize it by themselves, they work even harder to get it through "chain" mobility in which they save their earnings in order to educate their younger brothers or sisters left back in their home town. Whereas such behavior is not fully documented, nor has it been properly surveyed and analyzed, anecdotes telling of the deadly motivated behavior of ambitious female statusseekers are featured in newspapers from time to time. A story ${ }^{(6)}$ tells of a bus conductress at 32-year, who had been working since age 18 .

"By spending almost all her earnings, she succeeded in paying back a debt left by her father who died of a terminal disease on the hand, and helped by fully supporting two brothers of hers to graduate from senior high school. For the past 14 years, she has never eaten out and missed even lunch more often than not. And she, who has as yet to get married, has never bought any pieces of cloth for her own use, and slept at night in a make-shift room in the bus company's office."

How determined she has been in working toward her life goal is glimpsed in the miserable environment of the job she holds. According to a recent survey ${ }^{(7)}$, more than 40 per cent of the bus conductresses interviewed were found to have used stimulants to shake off drowsiness and fatigue from overwork. The survey report also said that more than half of the conductresses had suffered from such job-related diseases as gastroenteritis, athlete's foot and anaemia.

\section{Settlement patterns of inmigrants}

The way that urban inmigrants find their housing receives greater attention in concerned

(6) Dong-A Daily Neres, March 12, 1980.

(7) The Korea Herald, March 15, 1980. 
studies. This is so because finding adequate housings is as difficult for inmigrants as finding jobs. As a questionnaire survey (Yoon, 1975) reveals, the most difficult problem the Seoul-bound migrants of rural origin face immediately after their move is to get jobs (37 per cent). This is followed by difficulties with housing ${ }^{(8)}$. Their adjustment to urban life is greatly dependent upon housing arrangements which is closely linked with job-finding information.

At the outset, Yoon's studies $(1970 ; 1975)$ are useful to learn of the housing conditions of inmigrants to Seoul. When the first survey was undertaken in 1968, only 30 per cent of the inmigrants under investigation owned houses regardless of their physical and legal status, whereas 32 per cent rented houses with a deposit which should be paid in advance and in a lump sum, followed by 20 percent dwelling in houses with an arrangement of monthly deduction of the rent deposit paid in advance, and 16 per cent solving their shelter problems by boarding (Table 13). In 1972 when another survey was made by the same author quoted above, the housing status of the inmigrants was worse than before. At the time of their first arrival in Seoul, only 26 per cent or 502 out of the surveyed 1954 inmigrant households owned their homes. As time passes, the housing ownership rate by the inmigrants grows merely to about 35 per cent. In this connection, the house ownership ratio of the inmigrants makes it not difficult to find them in a poorer housing situation than the older residents, of whom 54.4 per cent owned their houses in Seoul, as of 1970 .

Nevertheless, the above findings do not give any clue as to whether the housing the inmigrants find is standard or not from the viewpoint of physical condition, and further,

Table 13. Housing status of inmigrants by migration type

\begin{tabular}{|c|c|c|c|c|c|c|c|c|c|c|c|}
\hline \multirow{3}{*}{$\begin{array}{l}\text { Migra- } \\
\text { tion type }\end{array}$} & \multicolumn{2}{|c|}{ Total } & \multicolumn{9}{|c|}{ Housing status } \\
\hline & & & Own & \multirow{2}{*}{$\mid \begin{array}{l}\text { Rent in a lu- } \\
\text { mp sum mo- } \\
\text { ney No. (\%) }\end{array}$} & \multirow{2}{*}{$\begin{array}{c}\text { Monthly } \\
\text { payment } \\
\text { No. (\%) }\end{array}$} & \multicolumn{2}{|c|}{$\begin{array}{l}\text { Company } \\
\text { residence }\end{array}$} & \multicolumn{2}{|c|}{ Boarding } & \multicolumn{2}{|c|}{ Others } \\
\hline & & & No. $(\%)$ & & & No. & & No. & $(\%)$ & No. & $(\%)$ \\
\hline & 1,535 & 100.0 & $543(35.4)$ & $565(36.8)$ & $359(23.4)$ & 16 & $(1.0)$ & 48 & (3.1) & 4 & $(0.3)$ \\
\hline $\begin{array}{l}\text { Family- } \\
\text { in-part }\end{array}$ & 249 & 100.0 & $54(21.6)$ & $117(47.1)$ & $51(20.6)$ & & & 20 & (10.1) & 2 & $(0.6)$ \\
\hline Single & 391 & 100.0 & $50(12.8)$ & $31 \quad(7.9)$ & $23 \quad(5.9)$ & 3 & $(0.9)$ & 277 & $(70.8)$ & 7 & $(1.7)$ \\
\hline $\begin{array}{c}\text { Collec- } \\
\text { tive }\end{array}$ & 51 & 100.0 & $26(51.0)$ & $8(15.7)$ & $12(23.5)$ & & & 5 & $(9.8)$ & & \\
\hline Total & $2,222(1$ & $100.0)$ & $673(30.2)$ & $721(32.4)$ & $445(20.2)$ & 19 & $(8.5)$ & 355 & $(16.0)$ & 13 & (5.8) \\
\hline
\end{tabular}

Source: Yoon (1970).

(8) Other difficult problems next to housing are identified "running what is called business by the respondents" (10 per cent), and "unfamiliarity with urban transportation conveniences" (8 percent). 
whether the housing was built with authorized permission or not. For this reason, the legal and physical status of shelters occupied by the inmigrants must be derived indirectly from statistics that show urban districts in which they find their housing. Of the inmigrant households covered by the survey, 58 per cent settled in standard residential areas or above, compared with 30 percent residing in substandard squatter areas, and about 10 per cent dwelling in non-residential areas poorly fit for minimum urban amenities.

Housing ownership patterns by residential area also are an important indicator of the well-being of the inmigrants in regard to housing conveniences. It was found that the patterns are closely associated with the residential locations of the inmigrants: in the case of substandard squatter areas, the housing ownership rate remains very low at a percentage of 22 , while the proportions securing housing on a key money and rental basis are recorded at 38 per cent and 31 per cent, respectively. On the other hand, the ownership rate of inmigrants who moved to standard residential areas accounted for 32 per cent. And.in these areas, the inmigrants, even if they could not own houses, usually pay key money for a house, or one or two rooms (41 per cent) which is more costly than houising accomodations on a rental basis (Yoon, 1975).

\section{Living conditions of squatters}

As for squatter settlers proper, information as to what extent the inmigrants settle down in squatter areas varies from government statistics to individual research. According to government statistics ${ }^{(9)}$, only 20 per cent out of all inmigrants to Seoul in 1970 71 settle down in urban substandard houses built without authorized permission. On the other hand, an individual study (Kwon et al, 1967: 73) revealed that almost 60 per cent of the surveyed squatters identify rural and urban areas other than Seoul as places of origin immediately before the present squatter settlement (Table 14). The underestimation of the number of inmigrants directed to squatter settlement in the government statistics seems, more or less, due to reluctance on the part of the Korean municipal governments to make public grim reality with which they have to cope.

From a spatial perspective, there is a quality study (Lee, 1977) dealing with squatter areas in Seoul, which describes their major features: (1) The total area of squatter settlement is about 15 per cent of the total residential area of Seoul. In a locational sense, most squatter settlements are scattered along river banks on the one hand, and high ground areas and hill-side slopes on the other hand. (2) The spatial distribution of the squatters

(9) Seoul Municipal Government, Seoul Statistical Yearbook, 1972. 
Table 14. Places of origin prior to squatter settlement

\begin{tabular}{l|r|r|r|r}
\hline \multirow{2}{*}{ Places of origin } & \multicolumn{2}{c|}{$\begin{array}{c}\text { Immediately before } \\
\text { squatter settlement }\end{array}$} & \multicolumn{2}{c}{$\begin{array}{c}\text { Before the residence immediately } \\
\text { prior to squatter settlement }\end{array}$} \\
\cline { 2 - 5 } & number & percent & number & percent \\
\hline Rural areas & 1,323 & 33.1 & 98 & 35.1 \\
Small towns & 271 & 6.8 & 27 & 9.7 \\
Cities & 670 & 16.7 & 76 & 27.2 \\
Seoul & 1,659 & 41.4 & 78 & 28.0 \\
Unknown & 80 & 2.0 & - & - \\
\hline Total & 4,300 & 100.0 & 279 & 100.0 \\
\hline
\end{tabular}

Source: Kwon, E-Hyuk et al. (1967:73).

is associated with the bus route systems. Many terminals for public transportation interconnect directly with squatter settlements, especially on the edge of the city. (3) High density squatter areas are geographically distributed in the area surrounding the central city. And (4) it seems likely that there is a significant correlation between the overall spatial distribution of squatters and the location of industrial employment structure in the city, although it is not proved by mapping analysis.

These findings lead to a tentative conclusion that subsistance income groups mainly comprising recent inmigrants more than any other locational variable seek transportation convenience to the central city where there are plentiful modern as well as traditional jobs. This observation implies a close association between the settlement and occupational mobility of the inmigrants ${ }^{(10)}$.

As far as socio-economic mobility of squatters is concerned, when asked why they moved into squatter areas, the squatters surveyed identify "hard living" as the prime reason(32.3 per cent). This is followed by such major reasons as "seeking after jobs" (21. 6 per cent), "cheap housing cost" (16.8 per cent) and "failure in business" (12.1\%) as shown in Table 15. Therefore it appears that poverty associated with hard living and failure in business might push them to move into squatter settlements (Kwon et al, 1967). In a sense, "push" theory makes more sense than "pull" theory in explaining migration motives of squatters.

(10) The locational behavior is also applicable to inmigrants well-prepared for new urban life in Seoul. Kwon (1972:262) points out that "when the settlement locations of the inmigrants are mapped, they appear to agglomerate along the major transit lines directly connected to the central business district. They also tend to follow rather strictly the equilibrium pattern between the rent and the transportation time-distance-cost to the central place of the city. Hence, the city of Seoul has been growing in a larger circle concentrically, with transportation lines radially extending from the center." 
Comparing the above findings with the survey quoted earlier, the squatters may for the most part belong to groups who feel "much worse" (5.8\%) and "somewhat worse" (9.7 $\%$ ), about living conditions after migration, as surveyed by Barringer (1974:22). It is also believed that the groups defining their urban life after migration as "about the same" usually find their shelter in squatter areas. To this extent, the way of life and behavior observed in the squatter settlements represent a substantial volume of the inmigrants who fall into the "worse-off" rather than "better-off" after-migration categories.

Furthermore, the same study (Kwon et al 1967) indicates that many squatters have a very hard time improving the quality of their lives even after a considerable period of living in squatter settlements. The main reasons for a difficult life are: no skills $(37.4 \%)$, other employment-related accounts such as a loss of job by family head (14.1\%) and failure in business $(6.1 \%)$, as seen in Table 16 . Their subsistence employment status primarily stems from detrimental family structures such as an increase of dependent families (10.5\%), single parent (8.0\%) mostly composed of mother and their children, a decrease of labor productivity due to old age (4.6\%), and sickness of family head (3.4\%) or family members (1.2\%). As a result, of the economically active labor force among squatters, 75.8 per cent remain unemployed (see Table 17). Even when employed, what they can find is mostly handy employment which comprises daily wage earning (47.9\%), peddling (15.9\%) and manual labor (12.0\%), as seen in Table 17.

Table 15. Reasons for moving into squatter areas

\begin{tabular}{l|r|r}
\hline \multicolumn{1}{c|}{ Reasons } & Number of households & Percent \\
\hline hard living & 1,289 & 32.3 \\
seeking after job & 864 & 21.6 \\
cheap housing cost & 673 & 16.8 \\
failure in business & 485 & 12.1 \\
lack of any definite plan & 169 & 4.2 \\
accompanying relatives & 133 & 3.3 \\
failure in farming & 108 & 2.7 \\
second generation's education & 51 & 1.3 \\
transportation conveniences & 47 & 1.2 \\
refuge from the Korean War & 29 & 0.7 \\
demolition of the previous shelter & 23 & 0.6 \\
born & 19 & 0.5 \\
unknown & 113 & 2.8 \\
\hline \multicolumn{1}{c}{ Total } & 4,003 & 100.0 \\
\hline
\end{tabular}

Source: Kwon et al (1967). 
Table 16. Reasons for hard lives of squatters by squatter location

\begin{tabular}{l|r|r|r|r|r}
\hline Reasons & $\begin{array}{r}\text { Riverside } \\
\text { of } \\
\text { tributaries }\end{array}$ & Flat & $\begin{array}{r}\text { River } \\
\text { bank of } \\
\text { the Han }\end{array}$ & Hillside & Average \\
\hline no skills & 33.3 & 24.6 & 45.7 & 39.8 & 37.4 \\
loss of job by family head & 10.9 & 16.9 & 10.4 & 16.0 & 14.1 \\
increase of dependent family & 5.8 & 19.1 & 8.7 & 10.4 & 10.5 \\
single parent(mother and kids) & 10.4 & 10.6 & 5.8 & 7.0 & 8.0 \\
failure in business & 7.7 & 2.1 & 7.1 & 6.5 & 6.1 \\
decrease of labor productivity due to old age & 4.6 & 6.2 & 3.5 & 4.9 & 4.8 \\
sickness of family head & 3.4 & 2.6 & 3.9 & 3.5 & 3.4 \\
sickness of family members & 0.9 & 1.7 & 0.6 & 1.5 & 1.2 \\
loss of earnings by military service & 1.3 & 1.9 & 0.6 & 0.7 & 1.0 \\
unknown & 21.7 & 14.3 & 13.7 & 9.7 & 13.5 \\
\hline Total & $100.0 \%$ & $100.0 \%$ & $100.0 \%$ & $100.0 \%$ & $100.0 \%$ \\
Number of households & 780 & 698 & 840 & 1,904 & 4,222 \\
\hline
\end{tabular}

Source: Kwon et al (1967:38).

As such, the subsistence economies do not easily allow squatters to improve themselves in housing status. This fact is borne out by the fact that most of them (64.8\%) have lived in squatter areas for one year or more (see Table 18). Furthermore, 33 per cent cannot afford to escape from the vicious cycle of squatter dwelling within 5 years or more. Nevertheless, a promising sign noticed in Seoul is the fact that there are found to be fewer cases of intergenerational squatter living in Seoul, as against common cases persisting for more than two generations, as observed in many underdeveloped countries. By the

Table 17. Employment status in squatter areas

\begin{tabular}{l|c|c}
\hline \multicolumn{1}{c|}{ Occupation } & $\begin{array}{c}\text { Economically active } \\
\text { labors }\end{array}$ & Employed labors \\
\hline none & 75.8 & - \\
daily wage earner & 11.8 & 47.9 \\
peddling & 3.8 & 15.9 \\
worker & 2.9 & 12.0 \\
managerial worker & 1.5 & 6.2 \\
small shop & 0.8 & 3.3 \\
carpenter, masonry & 0.4 & 1.8 \\
driver and his helper & 0.3 & 1.3 \\
newspaper delivery & 0.1 & 0.4 \\
begging & 0.1 & 0.3 \\
shoe-shine & 0.1 & 10.3 \\
others & 2.6 & 0.6 \\
\hline Total & 100.0 & 100.0 \\
Persons surveyed & 23,481 & 5,690 \\
\hline
\end{tabular}

Source, Kwon et al (1967:35). 
Table 18. Duration of dwelling at the present squatter house by squatter location

\begin{tabular}{l|c|c|c|c|c}
\hline \hline Duration of dwelling & $\begin{array}{c}\text { Location } \\
\text { tributaries }\end{array}$ & Flat area & $\begin{array}{c}\text { River bank } \\
\text { of the Han }\end{array}$ & Hillside & Average \\
\hline 3-6 months & 25.3 & 20.1 & 16.2 & 24.4 & 22.2 \\
6 months-1 year & 17.1 & 11.6 & 12.0 & 12.3 & 13.0 \\
1-5 years & 35.0 & 31.9 & 34.0 & 29.6 & 31.9 \\
over 5 years & 22.6 & 36.4 & 37.8 & 33.7 & 32.9 \\
\hline Total & $100.0 \%$ & $100.0 \%$ & $100.0 \%$ & $100.0 \%$ & $100.0 \%$ \\
Number of Households & 780 & 698 & 840 & 1,904 & 4,222 \\
\hline
\end{tabular}

Source: Kwon et al (1967:41).

way, most squatter households in Seoul have only one room, although 12.7 per cent occupy two rooms. The number of persons occupying one room is 4.3 persons on the average. More than 90 per cent of them are short of portable water and have no sewage(Kwon et al, 1968: 50 52). Half of the squatter houses are shanties made of thin board.

\section{Summary}

1. Information disseminated by relatives, friends and acquaintances on opportunities at the possible destination plays a great role in the decision-making and action-taking of Seoulward migration.

2. From the standpoint of migration units, family-in-part and single migration are generally better informed about the city than family as a whole. This observation brings the conclusion that chain migration prevails in Seoul inmigration.

3. Step-wise migration is not as popular as in many other developing countries. This is attributable to the fact that Korea is small in territory size and, accordingly, distance friction in migration is not significant. There is no ethnic segregation is Korea which is noted for homogeneity in culture and way of life. Consequently, there is neither social distance prohibiting extensive migration flows.

4. Similar to urban inmigrants found in other developing countries, the social costs that Seoul inmigrants might incur at their destination and origins do not concern them at all.

5. In regard to the question as to what extent inmigrants to Seoul achieve their aims, half of them are satisfied with living conditions after migration. However, 15.5 per cent feel worse about living conditions in Seoul. Those inmigrants feeling better-off seem to succeed in upward socio-economic mobility partly by intragenerational mobility and partly by intergenerational mobility.

6. It is much difficult for recent inmigrants to achieve upward mobility. Such is, 
particularly, the case of young, single migrants either male or female trying to find job opportunities at modern, urban sectors immediately after their move to Seoul.

7. Among young inmigrants who fail to achieve upward mobility, many females refuse to give up their goals. Instead, they work even harder to achieve it through "chain" mobility by saving their earnings in order to pay for the education of their brothers or sisters left behind in their home towns, even though they are involved in "underground" jobs such as bar girls and prostitution.

8. The adjustment of inmigrants to urban life of Seoul is closely related to housing arrangements, which, in turn, is closely linked with job information.

9. Housing ownership is an important indicator of the well-being of urban population on an individual basis. The rate for recent inmigrants is much lower than that for old residents in Seoul.

10. Regardless of whatever housing arrangements are accessible to recent inmigrants, four out of ten come to settle in substandard residential areas.

11. From a locational perspective, the spatial distribution of squatter is associated, among other reasons, with the bus route system.

12. As for squatters being joined by many of the recent inmigrants to Seoul, there is a close association between squatter settlements and squatters' occupational mobility. It may be seen in that the squatters under the survey identify "hard living" as the main reason, for moving into squatter areas.

13. Difficulties met by the squatters stem from lack of job skills and other employmentrelated accounts like a loss of job by family heads. Furthermore, their poor income status, for the most part, is attributable to such social factors as an increase of dependent families, single parents, a decrease of labor productivity due to old age, and sickness of family heads or economically active family members.

\section{Part III: Policies concerned with internal migration}

It is no exaggeration to say that in recent times in Korea there have been no specific, explicit policy measures aimed at improving the well-being of urban inmigrants. The only explicit migration policy which has come into existence to date is a population dispersal policy. But its purpose is primarily to control the size of the Seoul population, and is far removed from any policy consideration in favor of the urban poor including recent inmigrants to Seoul. Speaking for the urban poor, the central and local governments have shown 
little concern for them at all.

Off and on, local governments, in particular, the municipal governments of big cities have made nominal investments in low-cost housing construction for low income groups, squatter resettlement projects and wage-subsidy programs intended to provide subsistent income groups with minimum earnings. Even these welfare projects, primarily organized by the central government, however, have given priority to big cities rather than smaller-sized cities. Accordingly, they are often criticized by urban policy makers and academics who claim that these projects are explicitly or implicitly geared to attract rural outmigrants pushed toward big cities by the relatively declining rural economy. At any rate, there is little doubt that policy measures at any level of government that address the needs of the urban poor receive little attention among other priority policies. Why this is so can be answered through a brief review of the a planning process where the Seoul population dispersal plan was formulated.

\section{Seoul population dispersal plan in the national development strategy.}

Until recently, spatial policies including a migration policy have been given lower priority to an overriding sectoral approach seeking national economic development. No sooner had the so-called development decade of the sixties passed than the national economic policy orientation centered on growth maximization came under heavy pressure from the lagging regions. This brought the policy-makers and goverment planners to alter the previous policy course in such a way to take steps for regional equity, unless the latter would be detrimental to national efficiency.

Accordingly, the national planners have been moved to define the modernization process of the national economy in terms of spatial dimension. Incidentally, social concern is growing over such conspicuously increasing urban diseconomies as traffic jams and urban pollution which are ascribed to the overcrowed population in the relatively tiny urbanized area of the nation. In this context, social awareness requires the social problems mentioned above to be defined in the spatial dimension.

Thoughtful reflection on the previous development policy which was primarily concerned with the growth maximization of the national economy came to center on controlling the urban size of Seoul. The Seoul population dispersal plan was spelled out in early 1976. It should be noted that the population dispersal plan primarily aimed at (1) discouraging massive population movement from the countryside to Seoul, which witnessed an average rate of increase of $7.1 \%$ for the 15 years $1960 \sim 75$, and, accordingly, has been subjected to 
diminishing returns as the result of congestion and other urban deterioration; (2) diverting the future potential migration flow which would have been directed to Seoul to a few intermediatesized growth centers conceived as being in the stage of increasing marginal return with further population growth; (3) dispersing to the rest of the country development potential which would otherwise have been congested in Seoul at an increasing rate; and (4) attaining a more balanced spatial organization of the national economy than ever before, which would eventually bring about steady and continous growth rates of the national economy. (11)

How to control the urban size or disperse the urban population is an immediate question to be answered by the government planning team. The dispersal plan was spelled out to contain two major objectives: one to discourage the ever-persisting migration wave into the Seoul metropolitan region; and the other to relocate a good portion of Seoulites to designated local cities.

It seems likely that the first target can be effecttively met by growth center policy. The adoption of growth center policy is encouraged by French regional planning experiences which the government planners hardly failed to notice. France is noted for inventing the growth pole concept and is a forerunner in its policy application. Also, the French case is considered the most valuble and relevant lesson applicable to the current Korean situation on the grounds that both countries are suffering from growing spatial dualism.

A French regional plan recommending the implementation of growth center policy is stated to point out that an estimated $\$ 12,000$ is needed to provide adequate urban services for each family newly migrating into the Paris region, whereas these costs could be reduced to $\$ 8,000$, if the family would be diverted to medium-sized growth centers. Instead, if the migration flow toward Paris could not be decreased significantly, the French national economy might lose its relative advantage in competing with the other countries in the European Community (Sundquist, 1975). The point made by a French regional development authority is good enough to justify the valid applicability of a growth center policy to the Korean circumstances.

As a result, five medium-sized cities with populations between 200,000 and one million were designated as priority investment urban centers in 1978. Incidentally, these five growth centers have been observed to have increased rapidly in population due to their propulsive urban economies such as provincial administration centers and/or industrial complexes under the priority development projects of the central government. Rural outmig-

(11) The First Ministry without Portfolio, The Seoul Population Dispersal Plan, 1976. 
rants who are mostly low-skilled, poorly educated and young have contributed to the population growth of these cities. In contrast, a selective migration stream appears more likely to move into Seoul where job competitiveness is so high as to discourage negative selective migration.

Consequently, there increasingly appears to be a polarization between positive selective migrants who prefer Seoul, the primate city of Korea, and negative selective migrants who are destined to local mid-sized cities. This change in migration pattern provides a valid clue as to why urban riots took place in Pusan, the second largest city in Korea, and Masan, a newly bustling industrial city neighboring the former at the end of 1979. The social unrest was reportedly originated from a political issue in protest against the dictatorial rule of the incumbent political leadership. The rioters were joined by many low-skilled, youthful workers of rural origin.

A prominent scholar is quoted as explaining that the urban riots which were sparked by political causes at first suddenly exploded from the frustration young, uprooted inmigrants felt of new urban settings and lack of a sense of regional identity in their settlement places. He predicts that urban riots will occur more frequently, if appropriate policy measures aimed at improving the well-being of rural outmigrants are not taken. ${ }^{(12)}$

On the other hand, a moderate view may be taken toward urban riots: it seems unlikely that urban rioters, if there are any in the future, comprised of many new comers to cities, would not turn out to be "the radical marginals", as defined by Nelson(1973). It should be observed that they are as yet unorganized, and their level of socio-political awareness is low. Since low status and lack of contacts leave them more vulnerable to law and order, they are "particularly unlikely to choose aggressive political action to express their grievances".

Moreover, modern Korea has no ethnic segregation that might lead to urban disruption. Therefore, socio-cultural problems which Korea today encounters with the urban poor do not appear as complicated or hard to cope with, as found in, say, ethnically diverse countries. They may stem, at most, from economic hardship. To this extent, sccietal issues at stake surrounding the urban poor seem more susceptible to an enlighted economic policy weighted toward welfare considerations than to any other. In this sense, Korea

(12) The point was made by Prof. Tai-joon Kwon, Dean of Graduate School of Environmental Studies, Seoul National University, who spoke of "Searching for National Goals in 1980' s" from the standpoint of urbanization and quality of the environment, at a seminar organized by the Korean Society for Future Studies, March 2, 1980. 
enjoys a comparative advantage over ethnically complex developing countries in dealing with the urban poor. For this reason, however, there is the danger of the possibility that the urban poor in Korea might be given relatively little priority in pubic policy choices.

A second objective of the government's dispersal policy has been to relocate a portion of the existing urban population of Seoul into designated local areas. But this policy goal is more difficult than that of discouraging a migration wave. To reduce the urban size by a certain proportion calls for simultaneous moves of prominent job opportunities and other attractive urban amenities which have pumped a great number of migrants into Seoul. In making this attempt, a reduction of urban land designated for manufacturing activities and extensive expansion of urban renewal projects within the administrative boundaries of Seoul are conceived as priority projects. Policy ideas also include plans to control polluting industrial firms, which will be, if they move out beyond the boundaries of the city, rewarded by low-interest loans, tax-waivers and other fringe benefits. If undertaken as they are conceived, the policy measures would work toward cleaning up the urban environment and replacing more desirable urban land uses for manufacturing land use.

Nevertheless, these plans are susceptible to the criticism that they work against the wellbeing of low-income groups including recent inmigrants. They would be worse-off, because they would have to pay extra costs for either farther commuting distances to relocated job places beyond the municipal boundary or, if they were willing to make a residential relocation, new housing accommodation costs plus moving expenses. An alternative possibility is for them to find job opportunities equivalent to or better than the jobs they hold presently within their current commuting distances. This option, however, would hardly apply to most of them, because of their low-skill and, accordingly, very limited choices within the job market.

However, aside from the fact that low-income groups would be reluctant to move out of Seoul, manufacturing jobs, if any, recently relocated beyond the municipal boundary would be a good alterative choice for potential rural outmigrants intending to move into the Seoul metropolitan region. This contention explains why all the small and medium-sized cities neighboring to Seoul have recently shown an explosive population growth rate since the Seoul population dispersal policy was put into action.

Regardless of welfare consideration from the standpoint of the urban poor, it would be difficult to determine how effective the policy objectives of population dispersal by means of the relocation of manufacturing activities would be, unless modern management sectors 
would cease to concentrate in Seoul. As in many developing countries, urban jobs in Korea are hierarchically organized. Based on the urban employment structure model defined by Friedmann and Sullivan (1975), a urban job structure model (H-K.Kim,1976) is proposed to discuss the possibilities and difficulties met in the Seoul population dispersal plan. The model is illustrated as follows:

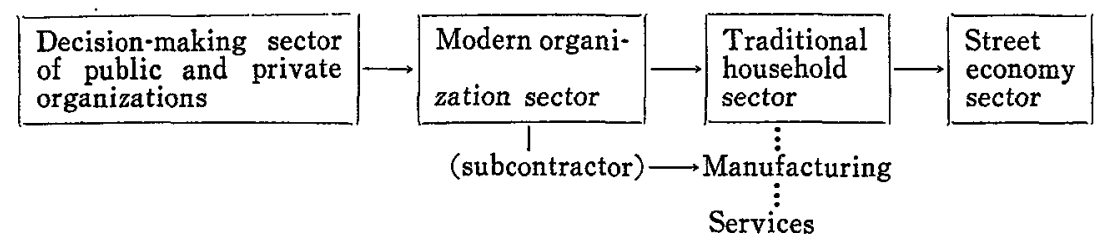

The model reads that the job locations of lower sectors as defined in the hierarchical structures of urban jobs are greatly dependent upon their respective upper echelons of job sectors. For instance, service activities belonging to the traditional household sector such as mentioned earlier are desperate for accessibility to modern organization sectors including corporate firms and public management institutes. And street economy sectors are oriented primarily toward the modern organization sector and partly toward traditional household sectors in their locational behavior. If applied to the case of Seoul, manufacturing sectors planned to be moved out of Seoul would have been relocated as effectively as modern organization sectors and, if possible, the decision-making sectors of management activities would move from their present locations congested in Seoul, which is the site of control of both private and public sectors.

The hierarchical relationship among various job sectors that the model refers to was seriously taken into account by the national spatial planner so that the effort to disperse the Seoul population resulted in a plan to establish a new capital city to which the office activities of the central government would move. At the moment, however, the new capital city under planning no longer receives political support due to an abrupt turn-over of political leadership in 1979.

The policy-making process noticed in the Seoul population dispersal plan brings some points to ponder from the standpoint of the urban poor's and, probably, the urban inmigrants. First, the policy makers within the central government have little changed their on-going policy objective centered on growth maximization of the national economy, while leaving equity consideration as a second choice. This idea is often justified on the grounds that equity can be significantly achieved, only if the national economy grows sufficiently to allow for fair distribution among social groups and regions. Until then, equity conside- 
ration can be taken into account only to the extent that growth maximization is not disturbed. In this context, growth center policy is conceived as the best policy option.

Second, the policy judgement advocating the dispersal plan is based on the fact that Seoul is increasingly suffering from urban diseconomies with the continuing population growth mainly caused by urban inmigration. This argument presupposes the likelihood of optimum city size, and its corresponding policy-making facilitated by such an aggregate indicator as population growth rates which Seoul has shown since the early $1960^{\circ} \mathrm{s}$. Nevertheless, it is not difficult to find that the policy judgement is based on a theory too poorly articulated to put forward to valid policy implications (Richardson, 1972).

On the other hand, the population growth rate as a policy indicator is too aggregate to evaluate its outcomes, particularly from the vantage point of the urban poor. In a sense, the adoption of the indicator is based on the idea that higher social costs in Seoul might occur due to too fast a rate of inmigration relative to the increase in urban capacity. But this theory still remains as much unproved as optimun city size theory (Richardson, 1972). Furthermore, the indicator is certainly useless in identifying who benefits and who loses, if and when it is taken as a policy guide in regard to migration policy. To the contrary, a theoretical contention (Thompson, 1972) that rural outmigrants are better-off in all likelihood by their move to urban sectors of any size seems valid enough to assert that any urbanization policy aimed at reducing the volume of inmigrants destined to big cities is contrary to their welfare. Therefore, it is certain that the dispersal plan of the Seoul population seems more likely to be detrimental to the welfare of the urban poor, the recent inmigrants, and impoverished potential rural outmigrants.

\section{Squatter relocation policy}

As far as the well-being of urban inmigrants is concerned, squatter relocation policies deserve an enlightened discussion. In an effort to deal with squatters in the late $1960^{\circ} \mathrm{s}$, the Seoul municipal government undertook an ambitious project aimed at the construction of a new town in an almost empty area $25 \mathrm{Km}$ south of Seoul. It was planned to accommodate a population of 350 thousand, of which about 70 per cent or 250 thousand were to be filled by squatters relocated by the city of Seoul. It was spelled out that the town would be built as a self-contained, self-supporting community, with specific provisions against becoming a bed town of Seoul. But the whole program was terminated at the end of 1971 when the city grew to have a population of 160 thousand consisting of some 110 thousand relocated squatters. 
Outcomes of the program turned out to be by no means satisfactory from the viewpoint of the poor's welfare. By the end of 1971, industries within the town employed only a total of 1320 , which barely accounted for 10 per cent of the economically active labor force which amounted to 14,000 of the relocatees. Thereafter, 30 per cent or more of the relocated squatters moved out of the new town by reselling their lands alloted by the government, due largely to the very limited job market and partly to grossly inadequate development of urban infrastructures and community facilities there. Many of them again moved to the central city of Seoul where, with their low skills, they could find the best job opportunities. Meanwhile, many relocated squatters who still remain in the town have continued to seek job opportunities in Seoul and, if they succeed in getting a job, commute to Seoul for work.

These outcomes may be evaluated from the standpoint of the urban poor's welfare. First, the resettlers from the new town served to make existing slum dwellings in the central city of Seoul even more over-crowded than before, for a considerable portion of squatter settlement areas had been demolished for the past few years by stringent government control on new squatter dwellings. Thus, both the existing and newly resettled squatters became worse-off in finding slum housing adequate for their income status, despite the fact that job opportunities were more available for the latter. Second, commuters from the town to Seoul had to spend much more for transportation cost in terms of both money and time in a longer haul between work and home than before when they had worked and lived in the central city of Seoul. Increased transportation cost might result in a negative income effect on their small earnings. Third, the longer haul by commuters, as mentioned above, might generate an additional social cost of traffic congestion in the central city. This side-effect should have been prevented for the benefit of all citizens in Seoul. The afore-mentioned discussion brings out the valuable lesson that squatter relocation policies are less likely to improve the poor's housing status, if the policy is not matched by necessary and sufficient considerations for the people's socio-economic welfare.

\section{Concluding remarks}

In summary, it can be concluded that the migration policy in the name of the Seoul population dispersal plan has no mention of the welfare of the urban poor as well as inmigrants to Seoul. Also, relocation policies that have been attempted by the Seoul municipal government remain distant from attaining a policy goal favoring the urban poor. The 
policies were carried out without any corresponding effort to improve income and/or employment status of the urban poor at the same time. There are many factors accounting for this failure. Among others, it seems attributable to planning styles predominant in Korea today.

As for the population dispersal plan, the spatial planners are observed with pursuing the GNP maximization goal which is sectorally defined by the economic planners. The spatial planning style takes place in such a way as to adapt itself to the national development goal proposed by the sectoral planners. In due course, spatial plans on any scale remain at best supplementary to the sectoral approach of national development.

As for Korean spatial planning practice, equity consideration is legitimated within the efficiency of the national economy. This is not to deny that it would be desirable to seek after, if possible, both policy goals at the same time. Nevertheless, the two development goals are usually characteristic of a trade-off relationship between each other. As the recent Korean case shows that spatial efficiency is preferred to equity considerations, the urban poor and new inmigrants receive little attention from the spatial planners, as observed in the plan-making process of the disperal plan.

Urban planners show themselves not to be free from shortcomings as shown in the sectoral planning styles. From time to time, they fall short of an acute awareness to make a distinction between a place's prosperity and the people's prosperity in their plan-making. A place's prosperity does not necessarily guarantee people's prosperity in the place. And people's prosperity differs within social groups. This welfare consideration should have been elaborated in the Seoul population dispersal plan.

Likewise, migration flow affects the well-being of those people joined and left by the migrants in their destinations and origins, respectively. For this reason, the question of who loses and who benefits should be fully examined when migration policies such as population dispersal from a big city are put into effect. From the standpoint of the people of big cities joined by rural outmigrants, the former will have to pay additional social costs such as traffic jams and overurbanization of public services. As such, the recent migration policy in Korea falls short of comprehensive consideration in regard to the quality of life of those who move, who are left over, and who are joined.

To put it differently, the planning practice mentioned above may be significantly associated with a predominant research style in migration studies, as found in today's Korea. In many cases, migration studies attempt to explain the cause and effect of migration in 
regard to urban and regional economies where people's move takes place. By employing regional econometric models which are aspatial in nature, the studies often move in such a way that net migration volume in a spatial economy is dependent upon differences of economic indicators such as wages, job opportunities, and incomes found in the destination and origin under study. This aggregate approach to migration study is too coarse to put forth policy implications valid enough to specify the impact of migratory flow on the concerned people. In this connection, almost all the migration studies dealing with Korean internal migration are poorly articulated from a theoretical perspective by taking the aggregate approach.

Meanwhile, as Korea enters the new decade of the $1980^{\circ}$ 's, time is drawing a little bit closer to expected changes of public policy style that will take into account welfare considerations to a more appropriate degree. The new tide in public policies may be attri buted to the turnover of political powers in 1979. A minor, but substantial change in policy style is found in that the 5-year economic development plan which has greatly contributed to rapid growth of the national economy will be renamed the "5-year socio-economic plan", beginning 1982 .

At this juncture, it might be worthy to mention that concerned people have for a long time been advocating a balanced socio-economic development strategy over the overriding sectoral approach of national development which has persisted throughout the past two decades of the $1960^{\circ} \mathrm{s}$ and $1970^{\prime} \mathrm{s}$. To this end, a research institute prepared a report ${ }^{13)}$ paying greater attention to the role of social development in economic development strategy, at the request of the Economic Planning Board in charge of long- and short-term economic development plans. A number of priority policy measures were recommended in an effort to improve the quality of urban life. Such policies are (1) the development of urban land to meet its exploding demand; (2) the expansion of housing; (3) the provision of convenient and cheap mass transport; (4) an increase of piped water supply; and (5) improving solid and liquid waste treatment.

But all these programs are implicitly directed at middle classes or above. Neither the urban poor, nor urban inmigrants are included in the target population. Even under these newly emerging circumstances where welfare considerations are taken into account to the same extent as an efficiency criteria in national development strategy, it is more than

(13) Korea Development Institute, A Perspective Plan of Socio-Economic Development: 1977-91, Seoul, 1976. 
necessary to specify costs and benefits of public policy with special reference to the target population. At the same time, this effort should be matched by micro-scopic studies ${ }^{(14)}$ on the quality of urban life.

\section{References and Bibliography}

Barringer, H.R.(1974), "Rural-Urban Migration and Social Mobility: Studies of Three Korean Cities," paper presented at the ILCORK Conference on Population Growth and Its Societal Impact, Korea, February 21-4.

Brandt, Vincent S.R.(1973), "Young Migrants to Seoul: Dimensions of Complexity," at Panel on Migration in Korea, Association for Asian Studies(mimeo.).

Breese, Jerald(1968), Urbanization in Newly Developing Countries, Englewood Cliffs: Prentice-Hall.

Cho, Lee-Jay (1973), "The Demographic Situation in the Republic of Korea," Papers of the East-West Popluation Institute, Honolulu, No. 29.

Findley, Sally(1977), Planning for Internal Migration: A Review of Issues and Policies in Developing Countries, Washington, D.C.: US Government Printing Office.

Friedmann, John(1973), "Urbanization, Planning and National Development, Beverly Hills: Sage Publications.

Friedmann, John and Flora Sullivan(1975), "The Absorption of Labor in the Urban Economy: The Case of Developing Countries," J. Friedmann and W. Alonso(eds.), Regional Policy, Cambridge: MIT Press.

Lee, Hahn-Soon(1973), "Population Redistribution and Inter-Provincial Migration," Urban Affairs, Vol. 8, No. 10 (Korean text).

Lee, Ki-Suk(1977), A Social Geography of Greater Seoul, Seoul: Po Chin Chai Co.

Lim, Hee-Sup(1976), "Mental Structures leading to Population Concentration in Seoul," Korean Society for Demography, Population Concentration in Seoul: Seminar Proceedings, Seoul.

Kim, Dae Young(1976), Characteristics of Internal Migration: The Case of Korea in 1965-70, Seoul: Korea Development Institute(Korean text).

Kim, Hyung-Kook(1976), "A Model Study on Urban Employment Hierarchy with policy recommendations for dispersing the population from the Seoul metropolitan region,"

(14) A new promising research style is found in G. Oscarsson and S. Öberg (1977). 
Korean Journal of Environmental Studies, Vol. 3, No. 1 (Korean text).

Kwon, E-Hyuk et al(1967), A Study on Subsistence Income Groups in Seoul: College of Medicine, Seoul National University (Korean text).

Kwon, Tai-joon(1972), "The Future Development Stages for Seoul," D. Dwyer (ed.), The City as a Center of Change in Asia, Hong Kong: Hong Kong Univ. Press.

Nelson, Joan(1973), "The Urban Poor: Disruption or Political Integration in Third World Cities?", J. Friedmann and W. Alonso (eds.), Regional Policy, Cambridge: MIT Press. Oscarsson G. and S. Öberg(1977), "Regional Policy and Interregional Migration-Matching Jobs and Individuals on Local Labor Market," Univ. of Gothenburg(mimeo.).

Richardson, H. (1972), "Optimality in City Size, Systems of Cities and Urban Policy: A Sceptic View," Urban Studies, Vol. 9, No. 1.

Shaw, R.P.(1975), Migration Theory and Fact: A Review and Bibliography of Current - Literature, Philadelphia: Regional Science Research Institute.

Sundquist, James(1975), Dispersing Population, Washington, D.C.: Brookings Institution. Thompson, W.(1972), "The National Systems and Cities as an Object of Public Policy," Urban Studies, Vol. 9, No. 1.

Yoon, Jong-Ju(1970; 1975), Findings from A Survey on Fertility and In-migration of Seoul, Seoul: Seoul Women's College.

Yu, Eui-Young(1978), "Internal Migration and Urbanization," H. Lee and T. Kwon(eds.), Korean Society: Population and Development, Seoul: Population and Development Research Institute (Korean text).

Statistics and Reports

Economic Planning Board, 1966, 1970, and 1975 Population and Housing Census.

First Ministry without Portfolio, The Seoul Population Dispersal Plan, 1976.

Korea Development Institute, A Perspective Plan of Socio-Economic Development: 1977 91, 1976.

Seoul Municipal Government, Seoul Statistical Yearbook, 1972. 